\title{
The Transformation Problem of Values into Prices of Production: Marx Errors or an Inattentive Reading of 'Capital'?
}

\author{
Valeriy Kalyuzhnyi
}

https://orcid.org/0000-0002-4974-5471

\begin{abstract}
The author presents the results of the discovery in Marx's works of the disparate elements of the theory of the original transformation of value into prices and the establishment of the general rate of profit. These results show:

(a) Marx's tables in Chapter 9 of Volume III of Capital do not represent the usual interrelated branches of the economy, but particular spheres of production, exempt from the double-counting of profits and wages, and producing only final commodities. The total value of these commodities is equal to the net social product.

(b) Marx carried out the original transformation of values into prices under the condition that wages remain unchanged. As a result, the first (chief) macroeconomic equality is fulfilled-the sum of the production prices for all net social products must be equal to the sum of its values. Also is fulfilled the second macroeconomic equality-the sum of profits of all sectors forming separate spheres of production must be equal to the sum of surplus values.

(c) Marx assumed that the original transformation takes place in two stages: in the first stage, average rates of profit are formed in separate spheres of production, comprising two sectors of production: A and B. Sector A produced of constant capital for the sphere's own need. Sector B releases the final product for an exchange with other particular spheres. In the second stage, is established the general rate of profit in sectors B. A property of the original conversion is some change in the level of real wages, especially noticeable when using numerical models with a few spheres of commodity production. Therefore, Marx introduces the hypothesis of mutual compensation of positive and negative deviations of prices from the values of commodities. The hypothesis is fully confirmed under the conditions of the law of large numbers.

(d) Marx also explains that non-equilibrium original prices of production, in which demand and supply of final goods do not coincide, can be transformed into equilibrium prices of production. For this to happen, corresponding changes in monetary wages, prices of constant capital, and the general rate of profit are necessary. However, the attainment of equilibrium prices was regarded by Marx as a secondary issue. At equilibrium prices, only the first (chief) macroeconomic equality is fulfilled.

The author in developing alternative methods of transforming value into original and equilibrium prices of production uses all of the above elements of the theory of transformation of values into production prices. First, he restores the double counting of profits and wages in Marx's table. Second, he applies an iterative procedure of sequentially establishing the average and general rate of profit in the sectors and spheres of commodity production.

The paper proposes new iterative calculation algorithms in the Excel program for the original and equilibrium transformation of values into production prices. The author tested the algorithms using the Wolfram Mathematica software. He also developed a method for converting the equilibrium production prices of goods back to their initial absolute values. This method refutes the well-known "eraser algorithm" by P. Samuelson. Ultimately, the author argues that Marx does not have the errors of transformation that his critics have attributed to him for so long.
\end{abstract}

\section{KEYWORDS}

Marx; transformation problem; original transformation; particular sphere of production; the equilibrium price of production; inverse transformation

JEL CODES

B14; B16; B24; B51; D58; E11; P16

\section{Introduction}

Marx introduced the theory of the transformation of values into the prices of production in Volume III of Capital ([1894] 1998). Engels published Volume III in 1894, eleven years after Marx's death. As an editor, Engels used Marx's manuscripts, written mostly between 1864 and 1865 (see Marx [1864-5] 2016). The theory of transforming the value of commodities into the price of production has been the focus of such researchers as Mühlpfordt $(1893 ; 1895)$, 
Böhm- Bawerk (1898), Komorzynski (1897), Sombart (1894), Schmidt (1889). In the first half of the twentieth-century, conducted studies on this topic Hilferding ([1904] 1920), Dmitriev ([1904] 1974), Tugan-Baranowsky (1905), Bortkiewicz ([1907] 1949; [1907] 1952), Charasoff (1910), Moszkowska (1929), Shibata (1933; 1939), and others.

Sweezy (1942) revisited Bortkiewicz's work in his famous book Theory of Capitalist Development: Principles of Marxist Political Economy. In 1949, Sweezy (1949) published a compilation on the transformation of values into the prices. In the compilation, Sweezy included three works related to the problem of transformation, including Bortkiewicz's work Correction of the fundamental theoretical constructions of Marx in the third volume of 'Capital', which Sweezy translated from German. Bortkiewicz argued that the prices of inputs to the production process should be determined simultaneously with the prices of output products resulting from the process of transformation of values into production prices. He was wrong when he wrote, "Marx simply states in general terms that the total price is equal to the total value. This statement is not only unprovable, but also false." (Bortkiewicz [1907] 1952, 11).

Thanks to Sweezy, the problem of transformation became the central topic of the Marxist and neo-Ricardian currents of economic science. They involved many researchers such as Dobb (1943), Winternitz (1948), May (1948), Meek (1956), Seton (1957), Samuelson (1971), Lippi (1979), and these are just a few of them. After that, critically minded economists ruthlessly attacked the Marx theory. They tried to prove the emptiness of value analysis. Sraffa carefully studied Bortkiewicz's work and his critique of Marx, especially between 1943 and 1945. Sraffa was likely on Marx's side rather than Bortkiewicz's (see Gehrke and Kurz 2006; Bellofiore 2008). He later summarized his research in his famous book Production of Commodities by Means of Commodities (Sraffa 1960). Unfortunately, this work caused many misunderstandings. It became the basis for the denial of the labour theory of value. Modern neo-Ricardian theorists show they can get the general rate of profit and price using technology data (matrix of unit direct cost coefficients, real wage vector, and vector of the coefficients of unit labour intensity). Steedman presents this direction in his work Marx after Sraffa (Steedman 1977). I have critically analysed Steedman's approach in an unpublished paper (Kalyuzhnyi 2014a). “...Value magnitudes," writes Steedman, "arc irrelevant to the proximate determination of the profit rate and of production prices." $(1977,66)$. However, without a vector of coefficients of specific labour intensity of production, which is directly proportional to the magnitudes of newly created value, it is impossible to calculate prices of production. Using coefficients of the specific labour intensity of production in calculating prices of production is equivalent to the use of the values of the corresponding goods. The using these coefficients and the matrix of coefficients of direct costs per unit of production, it is possible to determine the values of goods without the use of data on real wages. This means that values are primary to the prices of production.

In the 1970s, Bródy (1970), Morishima (1973), Shaikh (1973), Morishima and Catephores (1978) developed an Iterative Solution to the Transformation Problem (ISTP). They aimed the solution at eliminating the shortcomings of the Simultaneous Dual-System Interpretation (SDSI), which appeared thanks to Bortkiewicz. However, it turned out that ISTP is only an iterative method of mathematically solving a system of price equations under given postulates of invariance. Of course, this does not diminish the value of the ISTP method. This method allows the simulation of the actual transformation process as opposed to the simultaneous solution of a system of price equations leading to a similar result. 
In the 1980s, we saw an increasing number of responses to the then-dominant neo-Ricardian interpretation of Marx's theory. The first was the so-called New Interpretation (NI). Duménil (1983-4) and Foley (1982) first presented it independently. Lipietz (1982), Glick and Ehrbar (1987), Mohun (1994), Campbell (1997; 2002), and others have since developed it. In the third edition of the New Palgrave Dictionary of Economics (Foley and Duménil 2018, 8441), the authors renamed NI in the Single-system labour theory of value (SS-LTV). Foley had previously acknowledged that the model he and Duménil proposed was an interpretation of Marx's theory, not a solution to the transformation problem (Foley 2000, 22). However, Glick and Ehrbar (1987) and then Rieu (2006) got a numerical solution to NI using the threesector Bortkiewicz model. It coincides with my solution performed according to the Marx postulates of invariance, which refer to the original transformation (Kalyuzhnyi 2014a, 12-3). Therefore, I oppose Foley's point that NI is not a solution to the transformation problem. In particular, Bellofiore wrote:

... By interpreting the equality between the sum of labour-values and the sum of prices of production as that between the net product accounted in labour-values and production prices, while keeping constant in the transformation the value of labour power $\langle\ldots\rangle$ also the other Marxian equality between the sum of gross profits and the sum of surplus values results by definition. (Bellofiore 2014, 203)

Later we show that the two postulates of invariance, interpreted, as shown above, correspond to the postulates of invariance of the original transformation of values into prices of production, grounded by Marx.

A more radical approach followed NI. It is the Simultaneous Single-System Interpretation (SSSI). The authors of SSSI argue that in the same price system manifests both values and prices of production (Wolff, Roberts, and Callari 1982). Loranger showed that in the SSSI it is possible to isolate the price system of production as a subsystem and determine the rate of profit, and relative prices of production as in a typical neo-Ricardian solution (see Loranger 2004, 37).

The so-called Temporal Single-System Interpretation (TSSI) makes a cardinal change in the SSSI. In TSSI, the price depends on time, so the input and output prices may differ. In 1996, the book Marx and Non-Equilibrium Economics, edited by Freeman and Carchedi (1996) was published and helped to shape TSSI. Freeman, Kliman, and Wells then published The New Value Controversy and the Foundations of Economics (Freeman, Kliman, and Wells 2004). In 2007, Kliman published a book: Reclaiming Marx's Capital: A Refutation of the Myth of Inconsistency (Kliman 2007). In these publications, the authors summarize the thoughts of several Marxist economists over the past 30 years. By design, the TSSI authors aim to defend Marxist economic theory against critics (both bourgeois and those who claim to be Marxists).

Several authors criticized the methodology underlying TSSI: Foley (2011), Laibman (2000), Duménil and Levy (2000), Mongiovi (2002), Rieu (2003), Veneziani (2004), Mohun and Veneziani (2009). Laibman showed that the price calculation method using sequential iterations, which the authors used in TSSI, could also be a utility for determining equilibrium prices in the "neo-Ricardian" Bortkiewicz model or its analogues (Laibman 2000, 325). Of course, the dispute between supporters and opponents of TSSI is still ongoing (see Freeman 2018; Potts 2019; Honkanen 2020). Periodically, new papers on the problem of transformation get published. See, for example, Yoshihara and Veneziani (2013), Huang (2014), Diaz and Velasco (2016), Sandemose (2016), Mohun and Veneziani (2017), Burns (2017), MontesRojas (2017), Yoshihara (2017), Parys (2018), Bellofiore (2018), Pushnoi (2019), 
Wright (2019), Schefold (2016; 2019), Sinha (2019), Lopes (2019), Cuyvers (2020), Jaramillo (2020), Moseley (2020), Basu (2020), Shaikh (2021), Jefferies (2017; 2021), and others.

Moseley (2016) proposed a solution to the transformation problem that incorporates ideas specific to both TSSI and NI. A basic premise of Moseley's interpretation is that inputs of constant and variable capitals are presented in the theory of Marx's as if we assumed them sums of money. However, as noted by Ravagnani $(2005,91)$, the textual evidence of Capital contrasts with Mosley's basic premise. Moseley argues that the money sums of constant and variable capitals are unrelated to any physical quantities, whether measured (untransformed) in value or production-prices term. However, as Laibman wrote,

the values of input commodities are not 'constant' with respect to the transformation of value (an essentially logical problem in the concretization of the value categories in capitalist conditions). They are 'constant' in that their purchase is not the source of surplus value. (Laibman 2000, 316). ${ }^{1}$

In the 19th, 20th, and 21st centuries, economists attempted to solve the problem of transformation. These attempts have not been in vain. Each of the researchers has contributed to the analysis of this problem. However, economists have not yet solved the riddle of the direct and inverse transformation of absolute commodity prices. Many economists prefer to put forward their interpretations of Marx's theory and criticize each other's interpretations, rather than reread and rethink volume III of Capital as Marx wrote it. One must agree with A. Freeman, who wrote:

The modern formalization of labour value theory, however, is not the work of its authors but of twentieth-century writers redressing their alleged inconsistencies, in particular Marx's presentation of the quantitative relation between values and prices of production. (Freeman 1994, 1).

The purpose of this paper is to illuminate those elements of Marx's theory that have escaped the attention of researchers and are still in the shadows. The author examines these elements and on their basis offers a comprehensive solution to the problem of transformation in full accordance with Marx's concept.

\section{Reconstruction of Marx's Transformation Tables from Volume III of Capital}

Tugan-Baranovsky belongs to the idea of modifying Marx's three-product scheme of simple reproduction and using it to inverse the transformation of production prices into values. Marx considered in Volume II of Capital a scheme comprising the following departments and products.

Department I am engaged in the production of means of production. They are consumed entirely in Departments I and II. Department II produces consumer goods for the individual consumption of workers and capitalists. Marx divided the output of Department II into two subdivisions:

a) Articles of consumption, which enter into the consumption of the working class, and, to the extent that they are necessities of life — even if frequently different in quality and value

\footnotetext{
${ }^{1}$ Honkanen $(2020,106)$ indicates other inconsistencies in Moseley's interpretation, for example.
} 
from those of the labourers - also form a portion of the consumption of the capitalist class. For our purposes we may call this entire sub-division consumer necessities, regardless of whether such a product as tobacco is really a consumer necessity from the physiological point of view. It suffices that it is habitually such.

b) Articles of luxury, which enter into the consumption of only the capitalist class and can therefore be exchanged only for spent surplus value, which never falls to the share of the labourer. (Marx [1885] 1997, 402)

Tugan-Baranovsky transferred the necessities of life resources consumed by the capitalists from subdivision a) to subdivision b) and named the newly formed Department III "Production of capitalists' consumption goods" (Tugan-Baranovsky 1905, 171). Thus, Tugan-Baranovsky combines the different spheres of production, of which Marx makes up social production as a whole, into three production departments I, II and III.

Bortkiewicz borrowed the Tugan-Baranowsky model unchanged (see Bortkiewicz 1952, 319). Sweezy further renamed the product of the third department "capitalists' consumption goods (luxury goods)" and the product of the second department "workers' consumption goods (wage goods)" (Sweezy 1942, 109). After Sweezy, economists referred to the third sector product as luxury goods (see, for example, Blaug 1985, 231). They disguised Marx's idea that capitalists consumed some necessities of life. This contributed to ignoring the posttransformation fact of changes in real wages, which Marx wrote about as early as in his book Grundrisse:

For the worker, therefore, all three cases are possible: his gain or loss by the operation [the evening-up of profits] could = zero; the operation could depreciate his necessary wage so that it no longer suffices, hence depress it below the necessary minimum; lastly, it could create for him a surplus wage, which would amount to an extremely small share of his own surplus labour. (Marx [1857-61] 1986, 366)

The economists have made another deviation from Marx's theory. In tables of the $9^{\text {th }}$ Chapter of the III volume of Capital, they began to treat spheres of production by $\mathrm{I}$ to $\mathrm{V}$ as interdependent branches, instead of individual spheres of production. Only Mark Blaug noticed that in these tables, "the economy consists of five industries and none of the products of the five industries enters into the production of any other" (Blaug 1985, 229). ${ }^{2}$

In fact, in the tables, Marx did not consider branches of the industry but individual spheres of production producing final products. With this approach in Marx's postulate of invariance, the total social product is not the gross, but the net social product. Marx supports this interpretation of individual spheres of production as follows:

The means of production involved in each branch of production can be transferred from one sphere to another only with difficulty and therefore the various spheres of production are related to one another, within certain limits, as foreign countries or communist communities. (Marx [1894] 1998, 176)

Exchange does not create the differences between the spheres of production, but brings what are already different into relation, and thus converts them into more or less interdependent branches of the collective production of an enlarged society. In the latter case,

\footnotetext{
${ }^{2}$ Meek also wrote that Marx "takes 'five different spheres of production', deliberately assuming that none of the commodities concerned enters into the production of any of the others." (Meek 1956, 97).
} 
the social division of labour arises from the exchange between spheres of production, that are originally distinct and independent of one another. ${ }^{3}$ (Marx [1867] 1996, 357)

Marx formulates his major macroeconomic equality immediately after the presentation of the transformation tables: "... The sum of the prices of the production of all goods produced in society - the totality of all branches of production - is equal to the sum of their values." (Marx [1894] 1998, 159). Marx introduces this equality to preserve of magnitude newly created value when transforming values into prices of production. Marx then casts doubt on the postulate he formulated because of the apparent contradiction in it:

...Under capitalist production the elements of productive capital are, as a rule, bought on the market, and that for this reason their prices include profit which has already been realised, hence, include the price of production of the respective branch of industry together with the profit contained in it, so that the profit of one branch of industry goes into the cost price of another. (Marx [1894] 1998, 159)

But Marx immediately shows a way of resolving this contradiction. He proposes to exempt all spheres of production by I to V from double counting:

When we apply this calculation to the total social product, we have to make corrections; for example, the profit contained in the price of flax cannot appear twice, being at the same time part of the price of the canvas and profit of the flax producer. (Marx [1894] 2004, 162)

The wages in the price of flax also cannot appear twice. Marx wrote:

That the social product in question in the form of canvas cannot account twice for the total wages + surplus value contained therein, as the labor wage and surplus value of the spinner, flax farmer, coal producer, machine builder, etc., as well as the constant capital value of the weaver, is evident. (Marx [1868-81] 2008, 355)

Because of the elimination of double counting in Marx's tables, only those capitals, which produce final commodities, remain. They remain only because the corresponding "the commodity in question is itself an ultimate product, whose price of production does not pass into the cost price of some other commodity." (Marx [1894] 1998, 159). Consequently, Marx understands the total social product as the net (final) social product, and in his tables, he considers only end commodities.

The above information requires further analysis and research related to the transformation problem. In particular, questions arise about the recovery of double counting in Marx's table and how to use the reconstructed table to transform values into prices of production dynamically. There is also a need to clarify the terms that refer to independent spheres of production (see Marx [1867] 1996, 357).

I relate these questions to the need to clarify the economic essence of the spheres of production (with and without double counting). I have concluded that there are at least eight key signs that characterize Marx's system of spheres of production.

\footnotetext{
${ }^{3}$ For emphasis in quotations, regular italics indicates emphasis in the original and bold italics indicates emphasis added by me. I add brackets in quotations unless otherwise noted.
} 
Sign 1:

The portion, therefore, which will have to be used to buy back these consumed capital values, i.e., their cost price, depends entirely on the outlay of capital ... within the respective spheres of production. <... ... Cost prices (for the capitalist - V.K.) are specific. But the profit added to them is independent of his particular sphere of production, being a simple average per 100 units of invested capital. (Marx [1894] 1998, 157-8)

Sign 2:

They have as their (price of production - V.K.) prerequisite the existence of a general rate of profit, and this, again, presupposes that the rates of profit in every individual sphere of production taken by itself have previously been reduced to just as many average rates. These particular rates of profit $=m / C$ in every sphere of production, and must, as occurs in Part I of this book, be deduced out of the values of the commodities. Without such deduction the general rate of profit (and consequently the price of production of commodities) remains a vague and senseless conception. (Marx [1894] 1998, 156)

Sign 3:

... Deviations of the rates of profit in various ${ }^{4}$ spheres of production are continually balanced out into an average rate. (Marx [1894] 1998, 637)

Sign 4:

In our consideration of the transformation of surplus value into profit, we assumed that wages do not fall, but remain constant, because there we had to investigate the fluctuations in the rate of profit, independent of the changes in the rate of surplus value. (Marx [1894] 1998, 844-5)

\section{Sign 5:}

In applying this approach to the aggregate product of society, we must make some rectifications. Looking upon society as a whole, the profit contained in, say, the price of flax cannot appear twice - not both as a portion of the linen price and as the profit of the flax. (Marx [1894] 1998, 160)

Sign 6:

The sum of the profits for all the different spheres of production must accordingly be equal to the sum of surplus-values, and the sum of prices of production for the total social product must be equal to the sum of its values. (Marx [1894]1991, 273)

Sign 7:

For the purposes of the following analysis we may leave out of consideration the distinction between price of production and value, since this distinction disappears altogether when, as here, the value of the total annual product of labour is considered, i.e., the product of the total social capital. (Marx [1894] 1998, 818-9)

The entire value portion of commodities, then, in which the total labour of the labourers added during one day, or one year, is realized, the total value of the annual product,

${ }^{4}$ The translation from German as "separated spheres" is more appropriate here, rather than is "various spheres" (see Marx [1894] 1904, 184).

${ }^{5}$ I use here a more accurate translation from the edition that first appeared in Pelican Books 1981 and reprinted in Penguin Classics 1991. 
created by this labour, is divided into the value of wages, into profit and into rent. (Marx [1894] 1998, 820)

\section{Sign 8:}

He (Ramsay - V.K.) also brings up again Ricardo's exceptions. These latter will have to be discussed in that part of our text where we speak of the conversion of value into price of production. That is, very briefly, as follows. Provided that in the different trades the length of the working day (in so far as this is not compensated by the intensity of labour, the unpleasantness of the work, etc.) is the same, or rather the surplus labour is the same [as well as] the rate of exploitation, the rate of surplus value can change only if wages rise or fall. Such variations in the rate of surplus value=the rise or fall in wages, will affect the production prices of commodities in different ways according to the organic composition of capital. 〈...> Strictly speaking, all this hardly belongs to the discussion of the original conversion of values into production prices and the original establishment of the general rate of profit, since it is much more a question of how a general rise or fall in wages will affect production prices regulated by the general rate of profit. (Marx [1861-3] 1991, 261)

I developed a hypothesis based on the above signs of the sphere of production: Marx views each of the separated spheres as an elementary model of simple reproduction, comprising interconnected sectors A and B:

$$
\left.\begin{array}{l}
c_{\mathrm{Aj}}+v_{\mathrm{Aj}}+m_{\mathrm{Aj}}=w_{\mathrm{Aj}} \\
c_{\mathrm{Bj}}+v_{\mathrm{Bj}}+m_{\mathrm{Bj}}=w_{\mathrm{Bj}}
\end{array}\right\}
$$

where $w_{\mathrm{Aj}}$ and $w_{\mathrm{Bj}}$ is the output of sectors $\mathrm{A}$ and $\mathrm{B}$ of sphere $\mathrm{j}$, respectively; $c_{\mathrm{Aj}}$ and $c_{\mathrm{Bj}}$ is the constant capital of sectors $\mathrm{A}$ and $\mathrm{B}$ of sphere $\mathrm{j}$, respectively; $v_{\mathrm{Aj}}$ and $v_{\mathrm{Bj}}$ is the variable capital of sectors A and B of sphere $\mathrm{j}$, respectively; $m_{\mathrm{Aj}}$ and $m_{\mathrm{Bj}}$ is the surplus value of sectors A and B of sphere $\mathrm{j}$, respectively.

Sector A produces the means of production (constant capital) in the volume necessary to meet the demand of the separated sphere, that is:

$$
w_{\mathrm{Aj}}=c_{\mathrm{Aj}}+c_{\mathrm{Bj}} \text {. }
$$

Sector B produces some final product for commodity exchange with other particular spheres. Marx writes in Volume II of Capital

that, on the basis of simple reproduction, the sum of the values of $v+m$ of the commodity capital of I (and therefore a corresponding proportional part of the total commodity product of I) must be equal to the constant capital $\mathrm{II}_{\mathcal{C}}$, which is likewise taken as a proportional part of the total commodity product of department II; $\left.\mathrm{I}_{(\mathrm{v}}+\mathrm{m}\right)=\mathrm{II}_{\mathrm{c}}$. (Marx [1885] 1997, 401)

We will rewrite this Marx equality:

$$
\Sigma v_{\mathrm{Aj}}+\Sigma m_{\mathrm{Aj}}=\Sigma c_{\mathrm{Bj}} \cdot
$$

If we take the sum of all separate spheres of production, represented a model of simple reproduction (1), we will get:

$$
\left.\begin{array}{l}
\Sigma c_{\mathrm{Aj}}+\Sigma v_{\mathrm{Aj}}+\Sigma m_{\mathrm{Aj}}=\Sigma w_{\mathrm{Aj}} \\
\Sigma c_{\mathrm{Bj}}+\Sigma v_{\mathrm{Bj}}+\Sigma m_{\mathrm{Bj}}=\Sigma w_{\mathrm{Bj}}
\end{array}\right\}
$$

Then we insert the left part of equality (3) into the second equation of the system (4) and get: 


$$
\Sigma w_{\mathrm{Bj}}=\left(\Sigma v_{\mathrm{Aj}}+\Sigma m_{\mathrm{Aj}}\right)+\left(\Sigma v_{\mathrm{Bj}}+\Sigma m_{\mathrm{Bj}}\right)=V+M
$$

Equation (5) shows that the value of the total annual product of labour is equal to the sum of gross wages and gross profits, in which we include rent. The sum $(V+M)$ characterizes the annual newly created value, which is equal to the value of the net (or final) social product. Marx describes the economic sense of equation (5) in Volume III of Capital:

... It is quite correct to say that the component parts of commodities which make up the constant capital, like any other commodity value, may be reduced to portions of value which resolve themselves for the producers and the owners of the means of production into wages, profit and rent. This is merely a capitalist form of expression for the fact that all commodity value is but the measure of the socially necessary labour contained in a commodity. (Marx [1894] 1998, 838)

Note that all the translations of the third volume of Capital from German into English (1904, 1981, and 1998) have a characteristic flaw. The terms "branch" and "sphere" as well as the terms "separate sphere" and "special sphere" are arbitrarily translated using different synonyms. This shortcoming makes it difficult to understand the text of the third volume of Capital. Further, I propose we regard the separate (or independent) sphere of production as a set of sectors $A_{j}$ and $B_{j}$, sector $B_{j}$ as a particular sphere of production producing final product $\mathrm{j}$.

The separate sphere of production has several properties. We show the first property of the separate sphere of production $\mathrm{j}$ with the system of equations (1):

$$
\left.\begin{array}{l}
\left(c_{\mathrm{Aj}}+\Delta c_{\mathrm{Aj}}\right)+v_{\mathrm{Aj}}+m_{\mathrm{Aj}}=\left(w_{\mathrm{Aj}}+\Delta c_{\mathrm{Aj}}\right) \\
c_{\mathrm{Bj}}+v_{\mathrm{Bj}}+m_{\mathrm{Bj}}=w_{\mathrm{Bj}}
\end{array}\right\}
$$

It follows from (6) that an increase (or decrease) in the value of constant capital of sector A by magnitude $\Delta c_{\mathrm{Aj}}$ causes an increase (or decrease) in the product's value of sector $w_{\mathrm{Aj}}$ by the same magnitude $\Delta c_{\mathrm{Aj}}$, but has no effect on the value of the product of sector $w_{\mathrm{Bj}}$.

The following system of equation reflects the second property of a separate sphere of production:

$$
\left.\begin{array}{ccc}
c_{\mathrm{Aj}}+v_{\mathrm{Aj}}+\left(m_{\mathrm{Aj}}+\Delta w_{\mathrm{Aj}}\right) & =\left(w_{\mathrm{Aj}}+\Delta w_{\mathrm{Aj}}\right) \\
\left(c_{\mathrm{Bj}}+d_{\mathrm{Bj}} \Delta w_{\mathrm{Aj}}\right)+v_{\mathrm{Bj}}+\left(m_{\mathrm{Bj}}-d_{\mathrm{Bj}} \Delta w_{\mathrm{Aj}}\right) & w_{\mathrm{Bj}}
\end{array}\right\}
$$

The system (7) shows that an increase (decrease) in the selling price of the product of sector $\mathrm{A}_{\mathrm{j}}$ by $\Delta w_{\mathrm{Aj}}$ increases (decreases) the price of the constant capital of sector $\mathrm{B}_{\mathrm{j}}$ a by $d_{\mathrm{Bj}} \Delta w_{\mathrm{Aj}}$. Here $d_{\mathrm{Bj}}$ is the share of consumption of constant capital of sector $\mathrm{B}_{\mathrm{j}}$ in its total output in the separate sphere of production $\mathrm{j}$. However, the aggregate deviation of the price from the value of constant capital $\Delta w_{\mathrm{Aj}}$, caused by the change in the price of constant capital of sector $\mathrm{A}_{\mathrm{j}}$, does not affect the value of the final product $w_{\mathrm{Bj}}$ of the particular sphere of production $\mathrm{j}$. The price of the gross product of the separate sphere $\left(w_{\mathrm{Aj}}+\Delta w_{\mathrm{Aj}}\right)+w_{\mathrm{Bj}}$ changes by $\Delta w_{\mathrm{Aj}}$.

The third property of the separate sphere is that in it is A-sector we can always set such a deviation of the price from the value of the produced means of production that in its two sectors A and B we will get the same (average) rate of profit. Here, given (7), the value of the final product of the particular sphere of production will not change, i.e. $w_{\mathrm{Bj}}=\left(v_{\mathrm{Bj}}+d_{\mathrm{Bj}} \Delta w_{\mathrm{Aj}}\right)+\left(m_{\mathrm{Bj}}-d_{\mathrm{Bj}} \Delta w_{\mathrm{Aj}}\right)=$ const. 
We refer all three properties of the separate sphere of production to the first stage of transformation when in each of these spheres in sectors A and B we set average rates of profit. Here, the value of the final product of sector B remains unchanged, which guarantees the manifestation of the three properties under consideration. We can change the value of the final product of sectors $\mathrm{B}_{\mathrm{j}}$ only after we equalize their rates of profit to the general rate of profit, which happens at the second stage of transformation.

Marx showed in his transformation table only the second stage of transformation, just mentioning the first stage. In addition, he eliminated the double counting in the composition of the gross social product, removing from it all sectors A. As a result, Marx got a model of the final social product, which we can simplify without prejudice to its economic content and represent as:

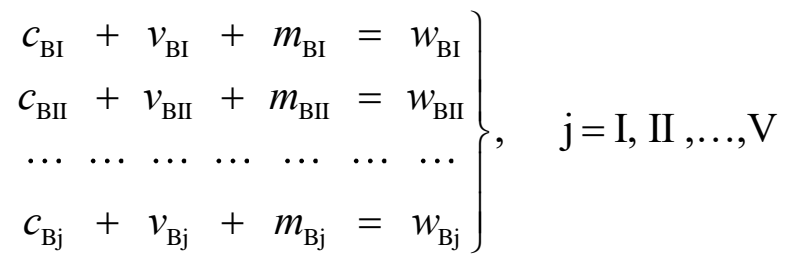

Rubin applied Marx's simplified numerical model of the final social product (Rubin [1928] 1990, 240), as did Samuelson (Samuelson 1971, 413-4). Marx also used simpler numerical models in manuscripts of the third volume of Capital (see Marx [1864-5] 2016, 121). In the third volume of Capital published by Engels, Marx added to his table the element of consumed constant capital, and for variable capital adopted the condition that it makes one turn per year. Samuelson, for example, simplified this table of Marx, explaining that he

ignored Marx's complication in which all of constant capital is not used up in one period's production - so the reader can, if he wishes, subtract from the numbers in my column's (3) and (5) the respective numbers [30, 19, 9, 45, 85] to get Marx's more complicated second table. Unfortunately for the reader in a hurry, the literature has mostly concentrated on the more complicated case, which merely slows down but does not alter the analysis. (Samuelson 1971, 413-4)

I reproduce Samuelson's numerical model in Table 1.

Table 1. Marx's Own Transformation Procedure (Samuelson 1971, 413-4)

\begin{tabular}{ccccccc}
\hline & $\begin{array}{c}\text { Capitals or Cost } \\
\text { Outlays }\end{array}$ & $\begin{array}{c}\text { Surplus } \\
\text { Values }\end{array}$ & Values & Rate of Profit, $\%$ & Prices & $\begin{array}{c}\text { Deviations of Price from } \\
\text { Values }\end{array}$ \\
\cline { 2 - 7 } & $(1)$ & $(2)$ & $(3)=(1)+(2)$ & $(4)=(2) /(1)$ & $(5)=(1) \cdot(1+0.22)$ & $(6)=(5)-(3)$ \\
\hline I & $80 c_{1}+20 v_{1}$ & $20 m_{1}$ & 120 & $20 \%$ & 122 & +2 \\
II & $70 c_{2}+30 v_{2}$ & $30 m_{2}$ & 130 & $30 \%$ & 122 & -8 \\
III & $60 c_{3}+40 v_{3}$ & $40 m_{3}$ & 140 & $40 \%$ & 122 & -18 \\
IV & $85 c_{4}+15 v_{4}$ & $15 m_{4}$ & 115 & $15 \%$ & 122 & +7 \\
V & $95 c_{5}+5 v_{5}$ & $5 m_{5}$ & 105 & $5 \%$ & 122 & +17 \\
& Average 100 & 22 & 122 & $22 \%$ & 122 & 0 \\
\hline
\end{tabular}

Unfortunately, we cannot use Samuelson's (or Rubin's) model for a complete reconstruction of Marx's concept of the transformation of values of commodities into prices of production. The fact is that in his model, Marx, in order to eliminate double counting, removed all the sectors A, which are necessary to model the process of continuous equalization of the rates of 
profit in separate spheres of production into the average rate of profit, and in particular spheres of production into the general rate of profit. ${ }^{6}$ (see Sign 3).

However, the analysis shows that it is possible to reconstruct sectors $A_{j}$ in Marx's model, simplified by Samuelson. Here we can rely on Marx's equality $v_{\mathrm{Aj}}+m_{\mathrm{Aj}}=v_{\mathrm{Aj}}\left(1+m^{\prime}\right)=c_{\mathrm{Bj}}$, where $m^{\prime}$ is the general rate of surplus value in Marx's model, and determine the unknown magnitude of variable capital in sectors $A_{j}$ :

The analysis shows that in Marx's model, simplified by Samuelson, we can reconstruct sectors $\mathrm{A}_{\mathrm{j}}$. To do this we can rely on Marx's equality $v_{\mathrm{Aj}}+m_{\mathrm{Aj}}=v_{\mathrm{Aj}}\left(1+m^{\prime}\right)=c_{\mathrm{Bj}}$, where $m^{\prime}$ is the general rate of surplus value in Marx's model, and determine the unknown magnitude of variable capital in sectors $A_{j}$ :

$$
v_{\mathrm{Aj}}=\frac{c_{\mathrm{Bj}}}{1+m^{\prime}} .
$$

We then determine the surplus value of sector $A_{j}$ :

$$
m_{\mathrm{Aj}}=c_{\mathrm{Bj}}-v_{\mathrm{Aj}} \cdot
$$

To determine the value of constant capital in sector $\mathrm{A}_{\mathrm{j}}$ in the simplest case we can establish in sectors $\mathrm{A}_{\mathrm{j}}$ and $\mathrm{B}_{\mathrm{j}}$ the same capital composition $c_{\mathrm{Aj}} / v_{\mathrm{Aj}}=c_{\mathrm{Bj}} / v_{\mathrm{Bj}}$, whence $c_{\mathrm{Aj}}=v_{\mathrm{Aj}}\left(c_{\mathrm{Bj}} / v_{\mathrm{Bj}}\right)$. However, we will come closer to reality if we set the magnitudes of constant capital $c_{\mathrm{Aj}}$ at an arbitrary level. ${ }^{7}$ Thus, we will provide a differentiated capital structure of sectors A and B in any of the individual spheres of production, and we will not change the value of production of sectors B as presented in Table 1. Consequently, we have discovered the possibility of recreating Marx's tables and giving them back what he could have removed, freeing them from double counting.

In particular, Rieu wrote about the problem of double counting (Rieu 1997; 2006). Rieu $(2006,269)$ concluded: "Those who do not accept the NI's postulates may consider double counting to be a pseudo-problem." He showed "that given the NI's specific formulation of the relationship between value and price, profit contained in constant capital is counted twice." That means that known solutions based on NI postulates do not eliminate double counting in the Tugan-Baranovsky-Bortkiewicz three-industry model, in which interdependent branches of production, rather than separate and particular spheres, appear.

${ }^{6}$ Marx stressed the need for such modeling in a veiled form in the title of Chapter 9 of Volume III of Capital: "Formation of a general rate of profit (average rate of profit) and transformation of the values of commodities into prices of production". The modeling of the process of continuous equalization of profit rates in separate spheres of production into an average rate of profit, as well as the process of formation of the general rate of profit and the transformation of the value of commodities into the price of production, remained incomplete in Volume III of Capital.

${ }^{7}$ About the neutral character of the influence of the magnitude of constant capital on the value of the total social product, Marx wrote in Volume II of Capital: “...The matter presents itself differently in the movement of social capital, i.e., of the totality of individual capitals, from the way it presents itself for each individual $\langle\ldots>$ capitalist. For the latter the value of commodities resolves itself into 1) a constant element (a fourth one, as Adam Smith says), and 2) the sum of wages and surplus value, or wages, profit, and ground rent. But from the point of view of society the fourth element of Adam Smith, the constant capital value, disappears." (Marx [1885] 1997, 383). 
In this model, the problem of eliminating double counting becomes a pseudo-problem. The real problem is the problem of restoring double account in the transformation table of Marx.

I solved this problem using formulas (9), (10), and the data from Table 1 . The result is a reconstructed numerical example of Marx supplemented by sectors-A producing means of production in separate spheres of production. I give this example in Table 2.

\section{The Solution to the Problem of Transformation of the Values of Commodities into the Original Prices of Production}

Now we can apply to own Marx's transformational procedure to the data of Table 2, using the general (average) rate of profit equal to $22 \%$. For this purpose, we redistribute the total surplus value of $=110$ in proportion to the capital of sector $B$, which produces and sells the final products on the market. We present the results of the transformation performed in Table 3.

Table 2. Reconstruction of the Example of Marx with the Allocation of Sectors Producing Means of Production in the Separate Spheres of Production

\begin{tabular}{|c|c|c|c|c|c|c|c|c|}
\hline Sphere & Sector & Gross Output Structure & $\begin{array}{c}\text { Constant } \\
\text { Capital }\end{array}$ & $\begin{array}{l}\text { Variable } \\
\text { Capital }\end{array}$ & $\begin{array}{l}\text { Surplus } \\
\text { Value }\end{array}$ & $\begin{array}{l}\text { Value of } \\
\text { Product }\end{array}$ & $\begin{array}{c}\text { Rate of Surplus } \\
\text { Value }\end{array}$ & $\begin{array}{l}\text { Rate of } \\
\text { Profit }\end{array}$ \\
\hline \multirow{2}{*}{ I } & A & Means of production & 100 & 40 & 40 & 180 & $100 \%$ & $28.571 \%$ \\
\hline & B & Final product & 80 & 20 & 20 & 120 & $100 \%$ & $20 \%$ \\
\hline \multirow{2}{*}{$\|$} & A & Means of production & 70 & 35 & 35 & 140 & $100 \%$ & $33.333 \%$ \\
\hline & B & Final product & 70 & 30 & 30 & 130 & $100 \%$ & $30 \%$ \\
\hline \multirow{2}{*}{ III } & A & Means of production & 50 & 30 & 30 & 110 & $100 \%$ & $37.500 \%$ \\
\hline & B & Final product & 60 & 40 & 40 & 140 & $100 \%$ & $40 \%$ \\
\hline \multirow{2}{*}{ IV } & A & Means of production & 170 & 42.5 & 42.5 & 255 & $100 \%$ & $20.000 \%$ \\
\hline & B & Final product & 85 & 15 & 15 & 115 & $100 \%$ & $15 \%$ \\
\hline \multirow{2}{*}{ V } & A & Means of production & 285 & 47.5 & 47.5 & 380 & $100 \%$ & $14.286 \%$ \\
\hline & B & Final product & 95 & 5 & 5 & 105 & $100 \%$ & $5 \%$ \\
\hline \multirow{3}{*}{\multicolumn{2}{|c|}{ Sum }} & Means of production & 765 & 195 & 195 & 1065 & $100 \%$ & $22.414 \%$ \\
\hline & & Total final product & 390 & 110 & 110 & 610 & $100 \%$ & $22 \%$ \\
\hline & & Gross output & 1065 & 305 & 305 & 1675 & $100 \%$ & $22.263 \%$ \\
\hline
\end{tabular}

Note: we highlight the numbers from the Marx example in bold here and below in the tables.

Table 3 shows that we have kept the prices of the final commodities from the simplified Marxian model presented in Table 1. However, compared to Table 2, the rate of profit in sector A of the separate sphere I have remained at $28.571 \%$, and in its B sector, it has increased from $20 \%$ to $22 \%$. The rate of profit in sector B of separate sphere II declined from $30 \%$ to $22 \%$, while sector A remained at $33.333 \%$, and so on.

Therefore, each separate sphere of production must begin a repeated process of equalizing the differential rates of profit into an average rate of profit. The process of formation of average rates of profit in each sphere corresponds to Sign 3 of the independent sphere of production.

We achieve equality of rates of profit by changing in the next period of reproduction $t+1$ the price of production of constant capital produced by sector A in each separate sphere of production. Therefore, we must determine the index of change in the price of constant capital $x_{\mathrm{jt}+1}$ based on the following modification of the model (1):

$$
\left.\begin{array}{l}
c_{\mathrm{Ajt}} x_{\mathrm{jt}+1}+v_{\mathrm{Ajt}}+m_{\mathrm{Ajt}}=w_{\mathrm{Ajt}} x_{\mathrm{jt}+1} \\
c_{\mathrm{Bjt}} x_{\mathrm{jt}+1}+v_{\mathrm{Bjt}}+m_{\mathrm{Bjt}}=w_{\mathrm{Bjt}}
\end{array}\right\}
$$


Table 3. First Stage: Transformation of the Value of Final Products into the Prices of Production according to the Marx Procedure

\begin{tabular}{|c|c|c|c|c|c|c|c|c|}
\hline Sphere & Sector & Gross Output Structure & $\begin{array}{l}\text { Constant } \\
\text { Capital }\end{array}$ & $\begin{array}{l}\text { Variable } \\
\text { Capital }\end{array}$ & $\begin{array}{l}\text { Surplus } \\
\text { Value }\end{array}$ & Price & $\begin{array}{c}\text { Rate of Surplus } \\
\text { Value }\end{array}$ & $\begin{array}{c}\text { Rate of } \\
\text { Profit }\end{array}$ \\
\hline \multirow{2}{*}{ I } & A & Means of production & 100 & 40 & 40 & 180 & $100 \%$ & $28.571 \%$ \\
\hline & B & Final product & 80 & 20 & 22 & 122 & $110 \%$ & $22 \%$ \\
\hline \multirow{2}{*}{$\|$} & A & Means of production & 70 & 35 & 35 & 140 & $100 \%$ & $33.333 \%$ \\
\hline & B & Final product & 70 & 30 & 22 & 122 & $73.333 \%$ & $22 \%$ \\
\hline \multirow{2}{*}{ III } & A & Means of production & 50 & 30 & 30 & 110 & $100 \%$ & $37.5 \%$ \\
\hline & B & Final product & 60 & 40 & 22 & 122 & $55 \%$ & $22 \%$ \\
\hline \multirow{2}{*}{ IV } & A & Means of production & 170 & 42.5 & 42.5 & 255 & $100 \%$ & $20 \%$ \\
\hline & B & Final product & 85 & 15 & 22 & 122 & $146.667 \%$ & $22 \%$ \\
\hline \multirow{2}{*}{ V } & A & Means of production & 285 & 47.5 & 47.5 & 380 & $100 \%$ & $14.286 \%$ \\
\hline & B & Final product & 95 & 5 & 22 & 122 & $440 \%$ & $22 \%$ \\
\hline \multirow{3}{*}{\multicolumn{2}{|c|}{ Sum }} & Means of production & 675 & 195 & 195 & 1065 & $100 \%$ & $12 \%$ \\
\hline & & Total final product & 390 & 110 & 110 & 610 & $100 \%$ & $22 \%$ \\
\hline & & Gross output & 1065 & 305 & 305 & 1675 & $100 \%$ & $22.263 \%$ \\
\hline
\end{tabular}

We determine the index $x_{\mathrm{jt+1}}$ after writing the system (11) in the form:

$$
\frac{w_{\mathrm{Ajt}} x_{\mathrm{jt}+1}-\left(c_{\mathrm{Aj}} x_{\mathrm{jt}+1}+v_{\mathrm{Ajt}}\right)}{\left(c_{\mathrm{Ajt}} x_{\mathrm{jt}+1}+v_{\mathrm{Ajt}}\right)}=\frac{w_{\mathrm{Bjt}}-\left(c_{\mathrm{Bjt}} x_{\mathrm{jt}+1}+v_{\mathrm{Bjt}}\right)}{\left(c_{\mathrm{Bjt}} x_{\mathrm{jt}+1}+v_{\mathrm{Bjt}}\right)} .
$$

The left part of the equality (12) determines the rate of profit sector A and the right, respectively sector $\mathrm{B}$. We define the magnitude of the index from (12) by the formula:

$$
x_{\mathrm{jt}+1}=\frac{\left(w_{\mathrm{Bjt}} c_{\mathrm{Ajt}}-w_{\mathrm{Ajt}} v_{\mathrm{Bjt}}\right)+\sqrt{\left.\left(w_{\mathrm{Ajt}} v_{\mathrm{Bjt}}-w_{\mathrm{Bjt}} c_{\mathrm{Ajt}}\right)^{2}+4 w_{\mathrm{Ajt}} c_{\mathrm{Bjt}} w_{\mathrm{Bjt}} v_{\mathrm{Ajt}}\right)}}{2 w_{\mathrm{Ajt}} c_{\mathrm{Bjt}}}
$$

We made calculations of the indices $x_{\mathrm{jt}+1}$ using the numerical data in Table 3. They gave the following result: $x_{\mathrm{I}}=0.9528721 ; x_{\mathrm{II}}=0.9176648 ; x_{\mathrm{III}}=0.8845205 ; x_{\mathrm{IV}}=1.0158706$; $x_{\mathrm{v}}=1.0617208$. After that, we can easily convert Table 3 into Table 4.

\begin{tabular}{|c|c|c|c|c|c|c|c|c|}
\hline Sphere & Sector & Gross Output Structure & $\begin{array}{l}\text { Constant } \\
\text { Capital }\end{array}$ & $\begin{array}{l}\text { Variable } \\
\text { Capital }\end{array}$ & $\begin{array}{l}\text { Surplus } \\
\text { Value }\end{array}$ & Price & $\begin{array}{c}\text { Rate of Surplus } \\
\text { Value }\end{array}$ & $\begin{array}{l}\text { Rate of } \\
\text { Profit }\end{array}$ \\
\hline \multirow{2}{*}{ I } & $A$ & Means of production & 95.287 & 40 & 36.230 & 171.517 & $90.574 \%$ & $26.780 \%$ \\
\hline & B & Final product & 76.230 & 20 & 25.770 & 122 & $128.851 \%$ & $26.780 \%$ \\
\hline \multirow{2}{*}{ II } & $A$ & Means of production & 64.237 & 35 & 29.237 & 128.473 & $83.533 \%$ & $29.461 \%$ \\
\hline & B & Final product & 64.237 & 30 & 27.763 & 122 & $92.545 \%$ & $29.461 \%$ \\
\hline \multirow{2}{*}{ III } & $A$ & Means of production & 44.226 & 30 & 23.071 & 97.297 & $76.904 \%$ & $31.082 \%$ \\
\hline & B & Final product & 53.071 & 40 & 28.929 & 122 & $72.322 \%$ & $31.082 \%$ \\
\hline \multirow{2}{*}{ IV } & $A$ & Means of production & 172.698 & 42.5 & 43.849 & 259.047 & $103.174 \%$ & $20.376 \%$ \\
\hline & B & Final product & 86.349 & 15 & 20.651 & 122 & $137.673 \%$ & $20.376 \%$ \\
\hline \multirow{2}{*}{$V$} & $A$ & Means of production & 302.590 & 47.5 & 53.363 & 403.454 & $112.344 \%$ & $15.243 \%$ \\
\hline & B & Final product & 100.863 & 5 & 16.137 & 122 & $322.731 \%$ & $15.243 \%$ \\
\hline \multirow{3}{*}{\multicolumn{2}{|c|}{ Sum }} & Means of production & 679.038 & 195 & 185.750 & 1059.788 & $95.256 \%$ & $21.252 \%$ \\
\hline & & Total final product & 380.750 & 110 & 119.250 & 610 & $108.409 \%$ & $24.300 \%$ \\
\hline & & Gross output & 1059.788 & 305 & 305 & 1669.788 & $100 \%$ & $22.348 \%$ \\
\hline
\end{tabular}

Table 4. Stage Two: Formation of Average Rates of Profit in Sectors A and B 
We observe in Table 4 the change in the average rates of profit in separate spheres of production by I to $\mathrm{V}$. This change does not affect the total value of the final social product $=610$. The gross profit of the economy remains unchanged $=305$. Thus, we have realized in the dynamics the fulfilment of the two postulates of invariance, adopted by Marx for the original transformation of the values of commodities into the prices of production.

The profit redistribution effect arising after the second stage of transformation is the change in the average profit rate in the manufacture of the final social product. Here this rate rose from $22 \%$ to $24.300 \%$. Note also that the profit rates of sectors B remain differentiated, despite some reduction in their variability. In particular, their coefficient of variation fell after the first and second stages of transformation from $54.9 \%$ to $24.4 \%$.

We will trace further changes in the structure of gross output if we multiple times repeat the procedure of two-stage transformation, the results of which are presented in Table 3 and Table 4. However, the initial table should now be Table 4, not Table 2. I have presented in Table 5 the results of the final step of the iterative calculations. ${ }^{8}$

According to the data in Table 5, the indices of price changes compared to the base value of the final product were as follows: $X_{\mathrm{BI}}=0.8509231 ; X_{\mathrm{BII}}=0.7693302 ; X_{\mathrm{BIII}}=0.7191675$; $X_{\mathrm{BIV}}=1.0653288 ; X_{\mathrm{BV}}=1.7588575$. The general rate of profit is $r=20.471 \% .{ }^{9}$

Given equality $c_{\mathrm{Bj}} X_{\mathrm{Bj}}=w_{\mathrm{Aj}} X_{\mathrm{Aj}}-c_{\mathrm{Aj}} X_{\mathrm{Aj}}=X_{\mathrm{Aj}}\left(w_{\mathrm{Aj}}-c_{\mathrm{Aj}}\right)=c_{\mathrm{Bj}} X_{\mathrm{Aj}}$, this result satisfies the following system of equations:

$$
\begin{aligned}
& \left(c_{\mathrm{AI}} X_{\mathrm{AI}}+v_{\mathrm{AI}}\right)(1+r)=w_{\mathrm{AI}} X_{\mathrm{AI}} \\
& \left(c_{\mathrm{BI}} X_{\mathrm{AI}}+v_{\mathrm{BI}}\right)(1+r)=w_{\mathrm{BI}} X_{\mathrm{BI}} \\
& \left.\left(c_{\mathrm{Aj}} X_{\mathrm{Aj}}+v_{\mathrm{Aj}}\right)(1+r)=w_{\mathrm{Aj}} X_{\mathrm{Aj}}\right\}, \mathrm{j}=\mathrm{I}, \mathrm{II}, \ldots, \mathrm{V} \\
& \left(c_{\mathrm{Bj}} X_{\mathrm{Aj}}+v_{\mathrm{Bj}}\right)(1+r)=w_{\mathrm{Bj}} X_{\mathrm{Bj}} \\
& \sum_{\mathrm{I}}^{\mathrm{j}} w_{\mathrm{Bj}} X_{\mathrm{Bj}}=\sum_{\mathrm{I}}^{\mathrm{j}} w_{\mathrm{Bj}}
\end{aligned}
$$

The unknowns in the system (14) are the price indices $X_{\mathrm{Aj}}, X_{\mathrm{Bj}}$, and the general rate of profit $r .^{10}$

The analysis of the concluding stage of the transformation in Table 5 shows that we have transformed the values of goods into original prices in exact accordance with Marx's theory. For example, Marx wrote:

Aside from the fact that the price of a particular product, let us say that of capital B, differs from its value because the surplus value realised in B may be greater or smaller than the profit added to the price of the products of $\mathrm{B}$, the same circumstance applies also to those commodities which form the constant part of capital B, and indirectly also its variable part, as the labourers' necessities of life. $\langle\ldots\rangle$ As for the variable capital, the $\langle\ldots\rangle$ one commodity receiving too little of the surplus value while another receives too much, so that

\footnotetext{
8 A special algorithm developed by the author in Excel (Kalyuzhnyi 2020a) provides automatic iterative calculations. The algorithm involves more than 1,500 iterations to achieve perfect calculation accuracy.

${ }^{9}$ For example, $X_{\mathrm{BI}}=102.111: 120 \approx 0.85092$.

10 Calculations performed at my request by Grigorii Sergeyevich Pushnoi (St. Petersburg) using Wolfram Mathematica showed that this alternative calculation produces the same result as my iterative solution method.
} 
the deviations from the value which are embodied in the prices of production compensate one another. (Marx [1894] 1998, 160)

Table 5. End Stage: Setting a General Rate of Profit in all Sectors of Separate Spheres of Production

\begin{tabular}{|c|c|c|c|c|c|c|c|c|}
\hline Sphere & Sector & Gross Output Structure & $\begin{array}{l}\text { Constant } \\
\text { Capital }\end{array}$ & $\begin{array}{l}\text { Variable } \\
\text { Capital }\end{array}$ & $\begin{array}{l}\text { Surplus } \\
\text { Value }\end{array}$ & $\begin{array}{l}\text { Original } \\
\text { Price }\end{array}$ & $\begin{array}{l}\text { Rate of Surplus } \\
\text { Value }\end{array}$ & $\begin{array}{l}\text { Rate of } \\
\text { Profit }\end{array}$ \\
\hline \multirow{2}{*}{ I } & A & Means of production & 80.950 & 40 & 24.760 & 145.709 & $61.899 \%$ & $20.471 \%$ \\
\hline & B & Final product & 64.760 & 20 & 17.351 & 102.111 & $86.756 \%$ & $20.471 \%$ \\
\hline \multirow{2}{*}{ II } & $A$ & Means of production & 53.018 & 35 & 18.018 & 106.036 & $51.481 \%$ & $20.471 \%$ \\
\hline & B & Final product & 53.018 & 30 & 16.995 & 100.013 & $56.649 \%$ & $20.471 \%$ \\
\hline \multirow{2}{*}{ III } & $A$ & Means of production & 36.312 & 30 & 13.575 & 79.887 & $45.249 \%$ & $20.471 \%$ \\
\hline & B & Final product & 43.575 & 40 & 17.109 & 100.683 & $42.772 \%$ & $20.471 \%$ \\
\hline \multirow{2}{*}{ IV } & $A$ & Means of production & 173.390 & 42.5 & 44.195 & 260.085 & $103.988 \%$ & $20.471 \%$ \\
\hline & B & Final product & 86.695 & 15 & 20.818 & 122.513 & $138.787 \%$ & $20.471 \%$ \\
\hline \multirow{2}{*}{ V } & $A$ & Means of production & 444.895 & 47.5 & 100.798 & 593.193 & $212.207 \%$ & $20.471 \%$ \\
\hline & B & Final product & 148.298 & 5 & 31.382 & 184.680 & $627.635 \%$ & $20.471 \%$ \\
\hline \multirow{3}{*}{\multicolumn{2}{|c|}{ Sum }} & Means of production & 788.565 & 195 & 201.346 & 1184.910 & $103.254 \%$ & $20.471 \%$ \\
\hline & & Total final product & 396.346 & 110 & 103.654 & 610 & $94.231 \%$ & $20.471 \%$ \\
\hline & & Gross output & 1184.910 & 305 & 305 & 1794.910 & $100 \%$ & $20.471 \%$ \\
\hline
\end{tabular}

A comparison of Table 5 and Table 2 shows that after transforming the values into original prices of production, we observe price deviations from the values in sectors A and B, which produce means of production and final products, respectively. But the monetary estimates of total variable capital $=305$ as well as gross profit $=305$ and final social product $=610$ remain unchanged. Only what did Marx mean by the indirect deviation of prices from the value of those commodities, which satisfy the vital needs of the workers? We will answer this question as follows. Suppose that in value prices (see Table 2) workers in all sectors of the economy bought with their wages $100 \%$ of the output of sphere I, $100 \%$ of the output of sphere III, and $3 / 7$ of the output of sphere V. Thus, we get the following equation characterizing the balance between supply and demand of commodities for workers:

$$
120 w_{\mathrm{BI}}+140 w_{\mathrm{BIII}}+3 / 7 \cdot 105 w_{\mathrm{BV}}=305 W_{v} .
$$

Here $3 / 7$ is the share of the final product of sphere $\mathrm{V}$ in the total consumer basket of workers.

Equation (15) shows that the value of workers' total consumption basket is equal to $305 W_{v}$. At the same time, workers receive the same wage $\sum_{\mathrm{I}}^{\mathrm{V}} v_{\mathrm{Aj}}+\sum_{\mathrm{I}}^{\mathrm{V}} v_{\mathrm{Bj}}=305 W_{v}$. Consequently, the economy is balanced and all prices are in equilibrium: $305 W_{v}=305 W_{v}$. Let us now turn to the original prices of production presented in Table 5. From here we take the same percentages of the production prices of goods I, III, and V, and obtain the new total price of the consumer basket of all workers:

$$
102.111 w_{\mathrm{BI}}^{\prime}+100.683 w_{\mathrm{BIII}}^{\prime}+3 / 7 \cdot 184.680 w_{\mathrm{BV}}^{\prime}=281.943 W_{v}^{\prime} .
$$

Since the workers receive the former wage at the nominal level $=305 W_{v}$, they can now buy (with the proportions of distribution unchanged) $1.082(\approx 350 / 281.943)$ times more consumer goods than before the conversion of values into prices of production. Thus, there was an indirect change in the cost of variable capital, which in this example is expressed in an increase in the level of real wages.

Marx considered the fact of the discrepancy between nominal and real wages after the original transformation. He mentioned this several times in Volume III of Capital. According to Marx, the contradiction between nominal and real wages is always resolved through the 
mutual compensation of positive and negative deviations of prices from the values embodied in the prices of production. I developed a custom program with a random number generator, which is necessary to confirm Marx's above thought (see Kalyuzhnyi 2020b, Sheet 4). First, the program generated two arrays of 250 numbers each, reflecting the absolute values of goods in the ranges of $\$ 1$ to $\$ 80$ at increased and decreased composition of capital $c / v$, respectively. The program then generated from these arrays two arrays of prices of production that deviated from the values between $1 \%$ and $20 \%$. The program then determined the percentage deviation of the price array from the value array using two price arrays of 500 products each. I give the result of 20 consecutive calculations below:

\begin{tabular}{|c|c|c|c|c|c|c|c|c|c|c|}
\hline $\begin{array}{l}\text { Number of calculation } \\
\text { Deviation of general sum of } \\
\text { prices from general sum of } \\
\text { values, \% }\end{array}$ & 0.38 & 0.94 & -0.12 & 0.69 & 0.17 & 0.22 & 0.37 & 0,10 & -0.01 & 0.51 \\
\hline $\begin{array}{l}\text { Number of calculation } \\
\text { Deviation of general sum of } \\
\text { prices from general sum of } \\
\text { values, \% }\end{array}$ & 0.52 & 0.30 & 0.79 & 1.43 & 0.59 & 0.28 & 0.83 & 0.36 & 0.59 & -0.05 \\
\hline
\end{tabular}

This result shows that despite the $20 \%$ limit deviation of commodity prices from values, their average deviation for the whole aggregate is only $0.44 \%$, and the maximum deviation is $1.43 \%$. If we double the above arrays, the average deviation of commodity prices from values decreases to $0.32 \%$ and the maximum deviation to $1.03 \%$. It means that with the existing number of goods, the price aggregates in the gross social product will be equivalent to their values.

Thus, experimental calculations show that the law of large numbers leads to the mutual compensation of price deviations from values. As a result, the sum price is approximately equal to the sum value for any of the components of the gross social product $(C+V+M)$.

Shaikh's empirical study showed that price aggregates are essentially equivalent to the corresponding aggregates of labour value. "As Sraffa had predicted, in actual conditions there is no effective difference between aggregates." (Shaikh 2021, 376-7; emphasis in the original). This result is one more confirmation of Marx's idea of the reciprocal compensation of prices' deviations from values under the original transformation.

But if we take only 3-5 industries (or spheres) when calculating the prices of production, there is usually no acceptable mutual compensation of price deviations from values. In the numerical model under consideration, comprising five separate spheres of production, we can accidentally reach the equality $305 W_{v}=305 W_{v}^{\prime}$. For example, if in Table 2 we increase in sector $A$ of the first sphere the value of constant capital from 100 to 210.195, we get equilibrium prices of production, as evidenced by equality

$$
137.128 w_{\mathrm{BI}}+98.122 w_{\mathrm{BIII}}+3 / 7 \cdot 162.749 w_{\mathrm{BV}}=305 W_{v} .
$$

The reader can check this calculation with a special algorithm (see Kalyuzhnyi 2020a).

\section{The Solution to the Problem of Transformation of the Values of Commodities into the Equilibrium Prices of Production}

Marx foresaw the main consequences of the original transformation of value into the price. He but also showed another way to resolve the contradiction between nominal and real wages. Marx wrote that 
the rise in commodity prices caused by an increase of the average profit must correspond to the rise of the money expression of the variable capital. Such a general nominal increase in the rate of profit and the average profit above the limit provided by the ratio of the actual surplus value to the total invested capital is not, in effect, possible without causing an increase in wages, and also an increase in the prices of commodities forming the constant capital. The reverse is true in case of a reduction. (Marx [1894] 1998, 178-9)

In Table 5, we have presented an example of the original transformation. It shows that the resulting prices of production are not in equilibrium. The general rate of profit is underestimated, and we overvalue real wages. According to Marx, in such a case, market relations should change the monetary value of wages, constant capital, and the general rate of profit. We have provided for these requirements in the following system of equations:

$$
\begin{aligned}
& \left(c_{\mathrm{AI}} X_{\mathrm{AI}}^{\prime}+v_{\mathrm{AI}} y\right)\left(1+r^{\prime}\right)=w_{\mathrm{AI}} X_{\mathrm{AI}}^{\prime} \\
& \left(c_{\mathrm{BI}} X_{\mathrm{AI}}^{\prime}+v_{\mathrm{BI}} y\right)\left(1+r^{\prime}\right)=w_{\mathrm{BI}} X_{\mathrm{BI}}^{\prime} \\
& \left(c_{\mathrm{Aj}} X_{\mathrm{Aj}}^{\prime}+v_{\mathrm{Aj}} y\right)\left(1+r^{\prime}\right)=w_{\mathrm{Aj}} X_{\mathrm{Aj}}^{\prime} \quad, \mathrm{j}=\mathrm{I}, \mathrm{II}, \ldots, \mathrm{V} \\
& \left(c_{\mathrm{Bj}} X_{\mathrm{Bj}}^{\prime}+v_{\mathrm{Bj}} y\right)\left(1+r^{\prime}\right)=w_{\mathrm{Bj}} X_{\mathrm{Bj}}^{\prime} \\
& \sum_{\mathrm{I}}^{\mathrm{j}} w_{\mathrm{Bj}} X_{\mathrm{Bj}}^{\prime}=\sum_{\mathrm{I}}^{\mathrm{j}} w_{\mathrm{Bj}} \\
& \sum_{\mathrm{I}}^{\mathrm{j}} y\left(v_{\mathrm{Aj}}+v_{\mathrm{Bj}}\right)=w_{\mathrm{BI}}^{\prime}+w_{\mathrm{BIII}}^{\prime}+\frac{3}{7} w_{\mathrm{BV}}^{\prime}
\end{aligned}
$$

where $w_{\mathrm{Bj}}^{\prime}=w_{\mathrm{Bj}} X_{\mathrm{Bj}}^{\prime} ; y v_{\mathrm{Aj}}=v_{\mathrm{Aj}}^{\prime}$ and $y v_{\mathrm{Bj}}=v_{\mathrm{Bj}}^{\prime}$.

In the system (17) the unknowns are the $X_{\mathrm{Aj}}^{\prime}$ and $X_{\mathrm{Bj}}^{\prime}$ indices, as well as the wage index $y$ and the new general rate of profit $r^{\prime}$.

I developed an iterative method for solution the system (17) (Kalyuzhnyi 2020a). The method was tested with a program Wolfram Mathematica, which gave a similar solution presented in Table 6 I give the general results of the transformation of Table 2 values into equilibrium production prices in Table 7

Table 6. Results of the Solution of the System (17) by Using the Program Wolfram Mathematica

\begin{tabular}{ccc}
\hline Sphere & $X_{\mathrm{Aj}}^{\prime}$ & $X_{\mathrm{Bj}}^{\prime}$ \\
\hline I & 0.774241962534851 & 0.8172663474421875 \\
II & 0.718920875200394 & 0.7312132472928730 \\
III & 0.686232450345859 & 0.6789688839259913 \\
IV & 1.006620934476756 & 1.0552623362679074 \\
V & 1.678213983381916 & 1.9091381308420554 \\
\hline$y=0.9148813814117829$ and $r^{\prime}=0.222278755165768$ & \\
\hline
\end{tabular}

Table 7 and Table 5 show that at equilibrium prices of production, the total rate of profit increases from $20.471 \%$ to $22.228 \%$, while the price of variable capital decreases by $8.5 \%$. These changes are consistent with Marx's assumptions (Marx [1894] 1998, 178-9). The exception is the change in the price of constant capital, which increased marginally by $0.5 \%$ in the final product. Marx assumed that this price should decrease. 
Table 7. The Result of the Calculation of Equilibrium Prices of Production and the General Rate of Profit in all Sectors of Separate Spheres of Production

\begin{tabular}{|c|c|c|c|c|c|c|c|c|}
\hline Sphere & Sector & Gross Output Structure & $\begin{array}{l}\text { Constant } \\
\text { Capital }\end{array}$ & $\begin{array}{l}\text { Variable } \\
\text { Capital }\end{array}$ & $\begin{array}{l}\text { Surplus } \\
\text { Value }\end{array}$ & $\begin{array}{c}\text { Equilibrium } \\
\text { Price }\end{array}$ & $\begin{array}{c}\text { Rate of Surplus } \\
\text { Value }\end{array}$ & $\begin{array}{l}\text { Rate of } \\
\text { Profit }\end{array}$ \\
\hline \multirow[t]{2}{*}{1} & A & Means of production & 77.424 & 36.595 & 25.344 & 139.364 & $69.255 \%$ & $22.228 \%$ \\
\hline & B & Final product & 61.939 & 18.298 & 17.835 & 98.072 & $97.472 \%$ & $22.228 \%$ \\
\hline \multirow{2}{*}{ II } & A & Means of production & 50.324 & 32.021 & 18.304 & 100.649 & $57.162 \%$ & $22.228 \%$ \\
\hline & B & Final product & 50.324 & 27.446 & 17.287 & 95.058 & $62.984 \%$ & $22.228 \%$ \\
\hline \multirow{2}{*}{ III } & A & Means of production & 34.312 & 27.446 & 13.728 & 75.486 & $50.016 \%$ & $22.228 \%$ \\
\hline & B & Final product & 41.174 & 36.595 & 17.286 & 95.056 & $47.237 \%$ & $22.228 \%$ \\
\hline \multirow{2}{*}{ IV } & A & Means of production & 171.126 & 38.882 & 46.680 & 256.688 & $120.055 \%$ & $22.228 \%$ \\
\hline & B & Final product & 85.563 & 13.723 & 22.069 & 121.355 & $160.816 \%$ & $22.228 \%$ \\
\hline & A & Means of production & 478.291 & 43.457 & 115.973 & 637.721 & $266.870 \%$ & $22.228 \%$ \\
\hline & B & Final product & 159.430 & 4.574 & 36.455 & 200.460 & $796.929 \%$ & $22.228 \%$ \\
\hline \multirow{3}{*}{\multicolumn{2}{|c|}{ Sum }} & Means of production & 811.477 & 178.402 & 220.029 & 1209.908 & $123.333 \%$ & $22.228 \%$ \\
\hline & & Total final product & 398.431 & 100.637 & 110.932 & 610 & $110.230 \%$ & $22.228 \%$ \\
\hline & & Gross output & 1209.908 & 279.039 & 330.961 & 1819.908 & $118.608 \%$ & $22.228 \%$ \\
\hline
\end{tabular}

The major result of the equilibrium transformation of values into prices of production is that the value of the final social product does not change and is still 610. But now the amount of wages is balanced with the total value of the workers' consumption basket:

$$
279.039 W_{v}^{\prime}=98.072 w_{\mathrm{I}}^{\prime}+95.056 w_{\mathrm{III}}^{\prime}+3 / 7 \cdot 200.460 w_{\mathrm{V}}^{\prime} .
$$

Equality (18) is a sign that the solution of the system of equations (17) leads to the equilibrium prices presented in Table 7. Also, Table 7 shows the following. At equilibrium prices, we do not achieve one of the two macroeconomic equalities that Marx postulated as unchanged during the original transformation. According to the first postulate of invariance, the value of the final social product does not change and equals 610, but we do not fulfil the second postulate of invariance - the sum of profit does not coincide with the sum of surplus value: $330.961>305$. In our example, the composition of the final social product changes from $305 V+305 M=610$ to $279.039 V^{\prime}+330.961 M^{\prime}=610$.

Marx devoted Chapter 11 of Volume III of Capital to this question, in which he investigated the effect of general variations in wages on the price of production. In particular, he drew the following conclusion:

Since the price of production of commodities produced by the average capital coincides with their value, the price of production of these commodities would have remained unchanged. A wage increase would therefore have caused a drop in profit, but no change in the value and price of the commodities. (Marx [1894] 1998, 198)

Marx also writes:

Since the price of production of the commodities of the average capital remained the same, equal to the value of the product, the sum of the prices of production of the products of all capitals remained the same as well, and equal to the sum of the values produced by the aggregate capital. The increase on one side and the decrease on the other balance for the aggregate capital on the level of the average social capital. (Marx [1894] 1998, 200)

Marx thus unequivocally clarifies that he bases the equilibrium transformation on only one postulate of invariance: the sum of the prices of the products of all capitals remains constant and equal to the sum of the values produced. The second postulate of invariance- the sum of the profits in all spheres of production must equal the sum of the surplus values - is succeeded by the condition of invariability of real wages. 
After that, Marx writes that in the entire Chapter 11:

The establishment of the general rate of profit and the average profit, and consequently, the transformation of values into prices of production, are assumed as given. The question merely was, how a general rise or fall in wages affected the assumed prices of production of commodities. This is but a very secondary question compared with the other important points analysed in this part. ${ }^{11}$ (Marx [1894] 1998, 202)

This question is also secondary to the theory of original transformation since the general increase or decrease of monetary wages compared to their nominal level leads to the failure of the postulate "the sum of profits in all spheres of production must equal the sum of surplus values". Marx intended this postulate for the original transformation. Therefore, its noncompliance at equilibrium prices has no theoretical consequences.

Thus, when Marx considers the transformation of values into equilibrium prices of production, he uses as his main postulate of invariance the equality between the sum of values and the sum of the production prices of the final products of particular spheres of production. We see that at equilibrium prices of production, the equality between the sum of surplus value and the sum of profit loses its priority. Now we know why this happens. Next, we show that surplus value does not disappear; we can identify it after the inverse transformation of equilibrium prices of production into initial values.

\section{A Solution to the Problem of Inverse Transformation Prices into Values}

Samuelson stated in his paper, not without triumph, that his attempts to the inverse transformation of production prices into values failed. He argued that after the inverse transformation "we ... can say in a dozen repetitive ways that... total of profit is not allocated by the value system according to where it was 'really produced'..." (Samuelson 1971, 417). Unfortunately, Samuelson did not give a single numerical example of the inverse transformation of production prices into value. Nor have such examples from Morishima and Seton, who, after Tugan-Baranovsky (1905), were among the first to consider the inverse transformation method (see Morishima and Seton 1961).

A review of the current literature (Ramos-Martínez and Herrera 1995; Foley 2011; Cogliano 2012; Sandemose 2016) showed that the inverse transformation problem is still under solution. According to Lopez $(2012$; 2019), the search for an inverse transformation method has been successful, and Pasinetti made the best presentation of the results in his book Lectures on Production Theory (1977). Pasinetti explains the inverse transformation algorithm and that it is possible. However, Pasinetti's solution concerns relative prices, not absolute prices. It does not allow us to refute Samuelson's (1971) “eraser algorithm”.

To show the importance of the inverse transformation procedure, I will reformulate the transformation problem as follows. Let us consider the system of the primary data characterizing the technological structure and intra-industry relations of the production of a certain set of goods in physical units of measurement. We should find two price systems based on this information. The first system would reflect values, and the second one would reflect production prices. We will solve the transformation problem then and only when we find an

\footnotetext{
${ }^{11}$ Marx has in mind the second part of Volume III of Capital, entitled "Conversion of Profit into Average Profit".
} 
algorithm for transforming the first system into the second and the second into the first one. Here, alternative systems reflecting values and production prices will be dualistic or divided into oppositions that complement each other. A historically formed complex of production relations in the economy-pre-capitalist and capitalist may condition each of these systems, respectively. From a logical point of view, such a decision would mean that we carry out a theoretical explanation of the average profit based on the law of value. This would mean that prices and money, which are invisible or present in any production model, we could explain only by labour value theory.

My paper (Kalyuzhnyi 2014b) presents a method of inverse transformation of production prices into values based on the three-sector Tugan-Baranovsky-Bortkiewicz model. I have shown that Samuelson was wrong. With my method, we allocate profits to where they were 'really produced'. I have also developed an inverse transformation method for Marx's fivesphere model. To convert equilibrium production prices to initial values (see Table 7 and Table 2), we must solve the following system of equations:

$$
\begin{aligned}
& c_{\mathrm{AI}}^{\prime} X_{\mathrm{AI}}+v_{\mathrm{AI}}^{\prime} y\left(1+m_{\pi}\right)=w_{\mathrm{AI}}^{\prime} X_{\mathrm{AI}} \\
& c_{\mathrm{BI}}^{\prime} X_{\mathrm{AI}}+v_{\mathrm{BI}}^{\prime} y\left(1+m_{\pi}\right)=w_{\mathrm{BI}}^{\prime} X_{\mathrm{BI}} \\
& \left.c_{\mathrm{Aj}}^{\prime} X_{\mathrm{Aj}}+v_{\mathrm{Aj}}^{\prime} y\left(1+m_{\pi}\right)=w_{\mathrm{Aj}}^{\prime} X_{\mathrm{Aj}}\right\}, \mathrm{j}=\mathrm{I}, \mathrm{II}, \ldots, \mathrm{V} \\
& c_{\mathrm{Bj}}^{\prime} X_{\mathrm{Aj}}+v_{\mathrm{Bj}}^{\prime} y\left(1+m_{\pi}\right)=w_{\mathrm{Bj}}^{\prime} X_{\mathrm{Bj}} \\
& \sum_{\mathrm{I}}^{\mathrm{j}} w_{\mathrm{Bj}} X_{\mathrm{Bj}}=\sum_{\mathrm{I}}^{\mathrm{j}} w_{\mathrm{Bj}}
\end{aligned}
$$

The unknowns in (19) are the indices of the conversion of production prices into values $X_{\mathrm{Aj}}$, $X_{\mathrm{Bj}}$, and the index of the change in wages $y$. The known amounts from Table 7 are $c_{\mathrm{Aj}}^{\prime}, c_{\mathrm{Bj}}^{\prime}$ and $v_{\mathrm{Aj}}^{\prime}$, and the average rate of surplus value is $m_{\pi} \cong 1.18608$.

If we use the first equation of any sphere of production, we get:

$$
X_{\mathrm{Aj}}=\frac{y v_{\mathrm{Aj}}^{\prime}\left(1+m_{\pi}\right)}{w_{\mathrm{Aj}}^{\prime}-c_{\mathrm{Aj}}^{\prime}} .
$$

The conversion of the second equation of any sphere of production yields the following result:

$$
X_{\mathrm{Bj}}=\frac{y\left(v_{\mathrm{Aj}}^{\prime}+v_{\mathrm{Bj}}^{\prime}\right)\left(1+m_{\pi}\right)}{w_{\mathrm{Bj}}^{\prime}} .
$$

Now we can solve the system of equations (19) using, for example, the program Wolfram Mathematica. However, we propose a simpler method of solution. We first conventionally assume that in all sectors A and B, the index $y=1$. Under this assumption, using system (19) and formulas (20) and (21), we can determine the initial values of outputs and constant capital of all sectors of a separate sphere of production. But we will not know the composition $(v+m)$ added values produced in these sectors.

We present in Table 8 the results of calculations of multipliers $X_{\mathrm{Aj}}$ and $X_{\mathrm{Bj}}$ by formulas (20) and (21) at $y=1$. 
Table 8. Price Multipliers for Inverse Transformation of Prices into Values

\begin{tabular}{ccc}
\hline Sphere & $X_{\mathrm{Aj}}$ & $X_{\mathrm{Bj}}$ \\
\hline I & 1.291586 & 1.223591 \\
II & 1.390974 & 1.367590 \\
III & 1.457232 & 1.472822 \\
IV & 0.993423 & 0.947632 \\
V & 0.595872 & 0.523797 \\
\hline
\end{tabular}

Next, we use the data from Table 7 and Table 8 to determine parameters $v_{\mathrm{Bj}}=v_{\mathrm{Bj}}^{\prime} X_{\mathrm{Aj}}$, $c_{\mathrm{Bj}}=c_{\mathrm{Bj}}^{\prime} X_{\mathrm{Aj}}$, and $\left(v_{\mathrm{Bj}}+m_{\mathrm{Bj}}\right)=w_{\mathrm{Bj}}-c_{\mathrm{Bj}}$, and present them in Columns 2, 3, and 4 of Table 9.

We then substitute the output values w from Table 9 into formula (15) and determine the value of the wage packet $W_{v}=305$. We can now easily determine the amount of surplus value $\Sigma m_{\mathrm{Bj}}=\Sigma w_{\mathrm{Bj}}-W_{v}=610-305=305$, and the wage share in the net social product

$$
q^{v}=W_{v} /\left(W_{v}+\Sigma m_{\mathrm{Bj}}\right)=305 /(305+305)=0.5 .
$$

Table 9. The Result of the Inverse Transformation of the Prices of Production in the Values for the Data in Table 7

\begin{tabular}{cccccc}
\hline \multirow{2}{*}{ Sphere } & Value & Constant Capital & Net Product & Variable Capital & Surplus Value \\
\cline { 2 - 6 } & $w$ & $c$ & $(v+m)$ & $v=q^{v}(v+m)$ & $m=\left(1-q^{v}\right)(v+m)$ \\
\hline 1 & 2 & 3 & 4 & 5 & 6 \\
\hline I & 120 & 80 & 40 & 20 & 20 \\
II & 130 & 70 & 60 & 30 & 30 \\
III & 140 & 60 & 80 & 40 & 40 \\
IV & 115 & 85 & 30 & 15 & 15 \\
V & 105 & 95 & 10 & 5 & 5 \\
Sum & 610 & 390 & 220 & 110 & 110 \\
\hline
\end{tabular}

Then we determine wages and surplus value in each particular sphere of production and fill in columns 5 and 6 (see Table 9). We determine the wage change index by the formula $y=W_{v} / W_{v}^{\prime} \cong 305: 279.039 \cong 1.09304$.

Thus, we determine the rate of actual surplus value if we know the structure of the package of goods included in real wages. According to Table 7, which presents the equilibrium prices of production, the apparent rate of surplus value is $116.2 \%$, and the real rate of surplus value is $100 \%$, which corresponds to the initial data in Table 2.

Therefore, the analysis shows that Samuelson's attempt (Samuelson 1971, 400) to present the problem of inverse transformation as an unsolvable problem proved untenable. Pasinetti was right when he wrote that in "a price system, the rate of surplus value, or "rate of exploitation' in Marxian terminology, can be obtained directly from the price-of-production system..." (Pasinetti 1977, 144). However, we should not forget that a prerequisite for calculating the total surplus value rate is not only the existence of a matrix of inter-industry coefficients but also a vector of direct labour coefficients. The matrix and the vector make it possible to calculate the values of goods even without information about the physical structure of the wage packet.

As for the content of Sraffa's works, Pasinetti wrote:

What really is then Piero Sraffa's conception? It is not easy to give a satisfactory answer to this question. In Sraffa's early notes one finds some hints at the problem of 'closing' the system, in terms of what wages and profits could buy. But these are passing and incidental 
remarks (or so they appear to me). My impression is that, on these aspects, the enormous mass of Sraffa's notes is still not sufficient to reveal any clear direction. It may well be that, in the end, he simply lacked time to apply his mind to these problems. (Pasinetti 2012, 1311)

It is up to the economists of the post-Sraffian generation to construct that part of the foundations of economic theory that Sraffa could not complete. (Pasinetti 2012, 1313)

Note that in the 21 st century many economists continue to address the problems of the labour theory of value as interpreted by Sraffa (1960). They are Lopes and Neder (2017), Wright (2019), Schefold (2016; 2019), and others. However, some of Sraffa's progressive ideas remain unrealized. In particular, Sraffa $(1960,105)$ proposed to decompose an integrated economic system into "as many parts as there are commodities in its net product, in such a way that each part forms a smaller self-replacing system the net product of which consists of only one kind of commodity. These parts we shall call 'sub-systems'." A sub-system is "is a vertically integrated 'slice' of the economy that produces a single commodity as final output and replaces the used-up means of production." (Wright 2019, 171).

We can conclude that Marx's reconstructed model, formed from the five separate spheres of production, results from dividing an integrated economic system into "as many parts as there are commodities in its net product." In this case, in a separate sphere of production, sector A reproduces used means of production. For the first time, I carried a method of dividing an integrated economic system into subsystems out in a paper (Kalyuzhnyi 2006).

This paper shows how we can disintegrate the Tugan-Baranowsky-Bortkiewicz threeindustry numerical model into two separate spheres producing final products for workers and capitalists. I have also shown two stages of iterative calculations, which include the sequential determination of the average rates of profit in separate spheres of production and the general rate of profit in particular spheres of production.

In this paper, I have presented alternative methods of direct and inverse transformation of prices. We can use these methods to investigate little-studied questions of the labour theory of value. As we know, Marx showed by a simple example that value prices are better than prices of production (see Marx [1894] 1998, 259-61). They more accurately capture the increase in social labour productivity from the realization of an investment project. I first reflected the results of my research on this issue in a paper (Kalyuzhnyi 2014a). Here I draw attention to the fact that Marx did not accidentally attach particular importance to the determination of value under socialism:

...After the abolition of the capitalist mode of production, but still retaining social production, the determination of value continues to prevail in the sense that the regulation of labour time and the distribution of social labour among the various production groups, ultimately the bookkeeping encompassing all this, become more essential than ever. (Marx [1894] 1998, 838)

From this, one of the central focuses on improving the labour theory of value and its practical use should be the development of a market pricing mechanism to ensure the implementation of the law of value in the transition period to socialism.

\section{Conclusion}

In this article, I argue that economists have so far overlooked some fundamental features of Marx's construction of his theoretical concept explaining the relationship between value and prices of production. 
First, Marx does not treat in the tables of Chapter 9 of Volume III of Capital the usual interdependent branches of the economy, but particular spheres producing only final products. Marx purges the monetary system of social product production from the double counting of profits and wages, and this causes a major misunderstanding of the text of Volume III of Capital. He excludes from the social product model all intermediate products (means of production for domestic consumption) produced in sector A of a separate sphere of production. As a result, only sectors B, which produce final products, remain in Marx's basic transformation table. The model, which includes only sectors B, perfectly reflects the final public product. The value of this product coincides with all newly created value as the sum of the annual costs of necessary and surplus labour. These costs do not change when we substitute the values of commodities for the prices of production. With this apparent property, Marx substantiates his central postulate of invariance - the sum of the production prices of the total social product must be equal to the sum of its value.

Second, Marx initially uses the assumption that the monetary value of wages (variable capital) does not change during the transformation of values into prices of production. The consequence of this assumption is the justification of the second transformational postulate of invariance - the sum of the profits of all the different spheres of production must be equal to the sum of surplus value. The meaning of these postulates of invariance becomes clear if we distinguish separate spheres of production as the sum of sector A (production of the intermediate product) and sector B (production of the final product), and also particular spheres of production as sectors B. The system of separate spheres produces the gross social product, and the system of particular spheres produces the final social product. In this paper, we consider the final social product in two ways:

(a) As the sum of the components of the particular spheres of production B:

$$
\Sigma w_{\mathrm{Bj}}=\Sigma c_{\mathrm{Bj}}+\Sigma v_{\mathrm{Bj}}+\Sigma m_{\mathrm{Bj}}
$$

(b) As the sum of wages and surplus value of sectors $\mathrm{A}$ and $\mathrm{B}$ :

$$
\Sigma w_{\mathrm{Bj}}=\left(\Sigma v_{\mathrm{Aj}}+\Sigma m_{\mathrm{Aj}}\right)+\left(\Sigma v_{\mathrm{Bj}}+\Sigma m_{\mathrm{Bj}}\right)=\left(\Sigma v_{\mathrm{Aj}}+\Sigma v_{\mathrm{Bj}}\right)+\left(\Sigma m_{\mathrm{Aj}}+\Sigma m_{\mathrm{Bj}}\right) \text {. }
$$

According to the basic postulate of the invariance of $\Sigma w_{\mathrm{Bj}}=$ const under condition $\left(\Sigma v_{\mathrm{Aj}}+\Sigma v_{\mathrm{Bj}}\right)=$ const, we obtain that under the original transformation the second postulate of the invariance of $\left(\sum m_{\mathrm{Aj}}+\Sigma m_{\mathrm{Bj}}\right)=$ const is also fulfilled.

The author proposed an innovative solution to the transformation problem, based on supplementing Marx's transformation table with A-sectors and a mechanism generating the average rate of profit in separate spheres of production composed of sectors A and B. This mechanism functions simultaneously with the mechanism of redistribution of the total surplus value of particular B-spheres (or B-sectors) of production is proportional to their capitals.

These two mechanisms provide dynamic formation of the total rate of profit in sectors A and B by successive iterative calculations. We conclude that Marx's tabular solution represents only the initial stage of the iterative transformation of values into prices, illustrating the formation of the total rate of profit in B-sectors. ${ }^{12}$ The complete transformation under the accepted postulates of invariance occurs because of two successive stages, which we repeat several times. In sectors A and B in the first stage, we form the average rate of profit, which leads to differentiation of the rates of profit in B-sectors, and in the second stage, we form the general rate of profit in sectors B. In dynamics, this process generate the general rate of profit in all sectors $\mathrm{A}$ and $\mathrm{B}$.

12 Shaikh $(1977,136 ; 2021,369)$ also Morishima and Catephores (1978) came to a similar conclusion but as a hypothesis. Marx could indeed implement an iterative process. However, he would have had to reestablish the double counting in his table first. 
The paper presents an iterative method for converting values into prices of production using the postulates of invariance of the original transformation according to the concept of Marx (Kalyuzhnyi 2020a, sheet 2). We tested this method using the Wolfram Mathematica program. The calculations showed that after the original transformation of values into prices of production if workers' nominal wages were unchanged, their real wages could change. It demonstrates the non-equilibrium nature of the original prices of production in the artificially created numerical models of simple reproduction. However, the basket of real wages in practice contains a huge number of consumer goods produced by capitals with different organic compositions. Here, the law of large numbers applies, and the discrepancy between nominal and real wages approaches zero. Marx relied on this principle and argued that an acceptable mutual compensation of positive and negative deviations of prices from value is possible. ${ }^{13}$

Marx briefly described a method for converting non-equilibrium prices of production into equilibrium prices when investigating the effect of wage fluctuations on the average rate of profit. The paper presents appropriate algorithms for such a transformation using an iterative procedure and the Wolfram Mathematica program (Kalyuzhnyi 2020a, sheet 2). The equilibrium transformation changes the distribution of the value of the same final social product $\Sigma w_{\mathrm{Bj}}$ into the income of workers $V=\left(\Sigma v_{\mathrm{Aj}}+\Sigma v_{\mathrm{Bj}}\right)$ and capitalists $M=\left(\Sigma m_{\mathrm{Aj}}+\Sigma m_{\mathrm{Bj}}\right)$.

However, the physical structure of the class distribution of the net social product does not change. Marx treated this issue in Chapter 11 of Volume III of Capital as secondary to the original transformation of values into prices of production. After the equilibrating transformation of the original prices of production, the sum of profit deviates from the sum of surplus value without changing the magnitude of the newly created value. This peculiarity obscures the origin of profit, but the operation of the law of large numbers leads to an approximate coincidence of total profit and total surplus value. For example, Engels, in a letter to Conrad Schmidt dated March 12, 1895, explained that

total profit and the total surplus value can correspond only approximately $\langle\ldots\rangle$ and any coincidence of the total price and total value other than one which constantly tends towards, and yet as constantly tends away from, unity, will be seen to be a sheer impossibility. (Marx [1892-5] 2004, 465)

The paper presents a method developed by the author of the inverse transformation of equilibrium prices of the production of commodities into initial absolute value prices (Kalyuzhnyi 2020a, sheet 3). Engels, in a letter to Werner Sombart of March 11, 1895, wrote that at production prices the "value $\langle\ldots\rangle$ is so thoroughly well-concealed that our economists can happily deny its existence." (Marx [1892-5] 2004, 462). The inverse transformation method allows us to calculate precisely the initial values of commodities and the distribution of surplus value over spheres of production, and on this basis to disprove Samuelson's "eraser algorithm".

The author provides links for downloading two algorithms (Kalyuzhnyi 2020a; 2020b), with the help of which it is possible to test the effectiveness of the transformation methods presented in this paper. Previously, the author has shown (see Kalyuzhnyi 2014a) that the methods of direct and inverse transformation allow evaluating alternative pricing principles (in value prices and production prices) in terms of their ability to assess the exact impact of investment projects on increasing the productivity of social labour. This area of research may become the major focus for the further development of the labour theory of value.

${ }^{13}$ It is Marx possible that he was familiar with the works of Jacob Bernoulli (1655-1705) and Simeon Poisson (1781-1840), published respectively in 1713 and 1837, devoted to the proof of the "law of large numbers". It is quite possible that Bortkiewicz, who dealt even with the "law of small numbers," failed to notice Marx's implicit reference to the "law of large numbers" on purpose. 


\section{Acknowledgments}

The author is grateful to thank Duncan Foley, Jean-Guy Loranger, Grigorii Pushnoi, Fabio Ravagnani, Tiago Camarinha Lopes, and Sergio Cámara Izquierdo for very useful comments.

\section{Declaration of Conflicting Interests}

The author declared no potential conflicts of interest with respect to the research, authorship, and/or publication of this paper.

\section{Funding}

The author received no financial support for the research, authorship, and/or publication of this paper.

\section{Corresponding Author:}

Valeriy Kalyuzhnyi, prospekt Peremogy, d. 64, kv. 279, Kharkiv, 61204, Ukraine.

Email:vvk1949vvk@gmail.com

\section{A note about the author}

Valeriy Kalyuzhnyi is an independent researcher (retired economist) living in Kharkiv, Ukraine. He has been Assistant Professor Department of Personnel Management and Labour Economics at the Kharkiv Regional Institute of Public Administration of the National Academy of Public Administration under the President of Ukraine and Deputy Director of the State Institute of Labour and Socio-Economic Research (Kharkiv). He holds 1982 a Ph.D. in economics from the Bardin Central Research Institute for Ferrous Metallurgy (Moscow). 


\section{References}

Basu, Deepankar. 2020. "Exploitation of Labour or Exploitation of Commodities?" Economics Department Working Paper Series 297. https://scholarworks.umass.edu/econ_workingpaper/297

Bellofiore, Riccardo. 2008. "Sraffa after Marx: An Open Issue." In Sraffa or an Alternative Economics, 68-92. New York: Palgrave Macmillan.

Bellofiore, Riccardo. 2014. "The Loneliness of the Long Distance Thinker: Sraffa, Marx, and the Critique of Economic Theory." In Towards a New Understanding of Sraffa Insights from Archival Research, 198-240. Edited by Riccardo Bellofiore and Scott Carter. Palgrave Macmillan.

Bellofiore, Riccardo. 2018. "The Multiple Meanings of Marx's Value Theory." Monthly Review 69 (11):31-48.

Blaug, Mark. [1962] 1985. Economic Theory in Retrospect. 4th ed. New York: Cambridge University Press.

Bohm-Bawerk, Eugen v. [1896] 1898. Karl Marx and the Close of his System. A Criticism. London: T. Fisher Unwin.

Bortkiewicz, Ladislaus von. [1907] 1949. "On the Correction of Marx's Fundamental Theoretical Construction in the Third Volume of Capital." In Karl Marx and the Close of His System, 199-221. New York: Augustus M. Kelley.

Bortkiewicz, Ladislaus von. [1907] 1952. "Value and Price in the Marxian System." International Economic Papers 2. London: MacMillan. (This is the second and third of a series of 3 papers published under this heading in 1906-7).

Bródy, András. 1970. Proportions, Prices and Planning. A Mathematical Restatement of the Labor Theory of Value. Budapest: Akademiai Kiadó.

Burns, Tony. 2017. "Marx, the Labour Theory of Value and the Transformation Problem." Capital \& Class 41 (3):1-18.

Campbell, Al. 1997. "The Transformation Problem: A Simple Presentation of the "New Solution'." Review of Radical Political Economics 29 (3):59-69.

Campbell, Al. 2002. "The Nature of Surplus Value in the 'New Solution'." Review of Radical Political Economics 34:69-73.

Charasoff, Georg von. 1910. Das System des Marxismus. Darstellung und Kritik, Berlin: Hans Bondy.

Cogliano, Jonathan F. 2012. “Smith's 'Perfect Liberty' and Marx’s Equalized Rate of Surplus-Value.” Working Paper 08/2011, New School for Social Research, Department of Economics. http://jonathancogliano.com/wp-content/uploads/2018/10/Cogliano-NSSRWP-082011-update2012.pdf

Cuyvers, Ludo. 2020. "Why Did Marx's Capital Remain Unfinished? On Some Old and New Arguments." Science \& Society 84 (1):13-41.

Diaz, Emilio, and Francisco Velasco. 2016. "The Transformation of Values into Prices of Production in Marx's Scheme of Expanded Reproduction." Review of Radical Political Economics 48 (3):394-416.

Dmitriev, Vladimir K. [1904] 1974. Economic Essays on Value, Competition and Utility (D. Fry, Trans. and D.M. Nuti, Ed.). Cambridge University Press.

Dobb, Maurice H. 1943. "Theory of Capitalist Development, by Paul M. Sweezy (Book Review)." Science and Society 7 (3):270-5. 
Duménil, Gérard, and Dominique Lévy. 2000. "The Conservation of Value: A Rejoinder to Alan Freeman." Review of Radical Political Economics 32 (1):119-146.

Duménil, Gérard. 1983-4. "Beyond the Transformation Riddle: A Labour Theory of Value." Science \& Society 47 (4):427-450.

Foley, Duncan, and Gérard Duménil. 2018. "Marxian Transformation Problem.” In The New Palgrave Dictionary of Economics, 8441-8452. 3rd edition, edited by Garett Jones et al. Basingstoke, Hampshire; New York: Palgrave MacMillan.

Foley, Duncan. 1982. "The Value of Money the Value of Labor Power and the Marxian Transformation Problem." Review of Radical Political Economics 14 (2):37-47.

Foley, Duncan. 2000. "Recent Developments in the Labor Theory of Value." Review of Radical Political Economics 32 (1):1-39.

Foley, Duncan. 2011. I. I. Rubin and the Inverse Transformation Problem. Paper presented at the Russian Academy of Sciences, Institute of Economics: Round Table on I. I. Rubin, December 15, 2011. Moscow.

Freeman, Alan, and Guglielmo Carchedi. Eds. 1996. Marx and Non-Equilibrium Economics. Edward Elgar: Aldershot, UK • Brookfield, US.

Freeman, Alan, Kliman Andrew, and Julian Wells. Eds. 2004. The New Value Controversy and the Foundations of Economics. Cheltenham, UK • Northampton, MA, USA: Edward Elgar.

Freeman, Alan. 1994. "Reappraising the classics - the case for a dynamic reformulation of the labor theory of value." MPRA Paper No. 1205, posted 18. December 2006. URL: http://mpra.ub.uni-muenchen.de/1205

Freeman, Alan. 2018. "Value and Price: A Critique of Neo-Ricardian Claims." Capital \& Class 42 (3):509-16.

Gehrke, Christian, and Heinz D. Kurz. 2006. "Sraffa on von Bortkiewicz: Reconstructing the Classical Theory of Value and Distribution." History of Political Economy 38 (1):91-149.

Glick, Mark, and Hans Ehrbar. 1987. "The Transformation Problem: An Obituary." Australian Economic Papers 26 (49):294-317.

Hilferding, Rudolf. [1904] 1920. Böhm-Bawerk's Criticism of Marx. Glascow: Socialist Labour Press.

Honkanen, Pertti. 2020. "The Transformation Problem and Value-Form: Methodological Comments." In Confronting Capitalism in the 21st Century. Lessons from Marx's Capital, 91-124. Edited by Marc Silver. Palgrave Macmillan.

Huang, Kuochih. 2014. "Chinese Studies on the Transformation Problem: A Critical Review.” December 24.

https://pdfs.semanticscholar.org/dca6/cd9aa014d4ee38df1fccfe415825e2e55e40.pdf

Jaramillo, Samuel. 2020. "Towards a Renewal of the Marxist Theory of Value. Recent Debates.” (August 28, 2020). Documento CEDE No. 32.

http://dx.doi.org/10.2139/ssrn.3684719

Jefferies, William. 2017. "Piero Sraffa and the Production of Commodities by Means of Magic." Critical Sociology 43 (3):479-94.

Jefferies, William. 2021. "Marx's Forgotten Transformation Solution: The Transformation of Values into Prices of Production in Marx's Grundrisse and Maksakovsky's The Capitalist Cycle." History of Economics Review, DOI: 10.1080/10370196.2021.1952004

Kalyuzhnyi, Valeriy. 2006. "The Full Solution of a Problem of Commodity Values Transformation into Production Prices." Ukrainian journal Ekonomist 6 (236):25-31 (in English). 
Kalyuzhnyi, Valeriy. 2014a. The Transformation Problem: Erroneous Arguments of TuganBaranowsky, Bortkiewicz and Steedman. http://dx.doi.org/10.2139/ssrn.2520362 (in Russian).

Kalyuzhnyi, Valeriy. 2014b. A New Look at the Problem of the Transformation of the Value of Commodities into the Price of Production. http://vvkaliuzhnyi.boxingdo.com/images/Kaliuzhnyi05a.pdf (in Russian).

Kalyuzhnyi, Valeriy. 2020a. The Solution to Marx's Transformation Problem in the Direct and Inverse Formulation (Programs for Transformational Calculations and Illustration of the Effect of the Law of Large Numbers). https://doi.org/10.7910/DVN/UKI7SC Harvard Dataverse.

Kalyuzhnyi, Valeriy. 2020b. Universal Algorithm of Direct and Inverse Prices

Transformation for a Three-Sector Model of Simple Reproduction. https://doi.org/10.7910/DVN/5ZTOOC Harvard Dataverse.

Kliman, Andrew. 2007. Reclaiming Marx's Capital: a Refutation of the Myth of Inconsistency. Lanham, MD: Lexington Books.

Komorzynski, Johann v(on). 1897. „Der dritte Band von Karl Marx ,Das Kapital': eine Kritische Abhandlung über die Arbeitswerttheorie und die Sozialistische Lehre vom Kapitals ertrage. “ Zeitschrift für Volkswirtschaft, Sozialpolitik und Verwaltung 6 (2):242299.

Laibman, David. 2000. "Rhetoric and Substance in Value Theory: An Appraisal of the New Orthodox Marxism." Science \& Society 64 (3):310-332.

Lipietz, Alain. 1982. "The So-Called 'Transformation Problem' Revisited.” Journal of Economic Theory 26 (1):59-88.

Lippi, Marco. 1979. Value and Naturalism in Marx. London: New Left Books.

Lopes, Tiago Camarinha. 2012. "As fases históricas do debate sobre a transformação dos valores em preços de produção" [The Historical Phases of the Debate on the Transformation of Values into Production Prices]. Revista de Economia Política 32 (2):315-335 (in Portuguese).

Lopes, Tiago Camarinha. 2019. The Transformation Problem of Values into Prices: From the Law of Value to Economic Planning. New Proposals: Journal of Marxism and Interdisciplinary Inquiry 10 (1): 29-42.

Lopes, Tiago Camarinha, and Henrique Dantas Neder. 2017. "Sraffa, Leontief, Lange: The Political Economy of Input-output Economics.” EconomiA 18 (2):192-211.

Loranger, Jean-Guy. 2004. "A Profit-Rate Invariant Solution to the Marxian Transformation Problem." Capital \& Class 28 (1):23-58.

Marx, Karl. [1894] 1904. Das Kapital. Kritik der politischen Ökonomie. Dritter Band, zweiter Theile. Zweite Auflage. Hamburg: Otto Meissners Verlag.

Marx, Karl. [1857-61] 1986. Karl Marx, Frederick Engels: Collected Works, Volume 28. New York: International Publishers.

Marx, Karl. [1861-3] 1991. Karl Marx, Frederick Engels: Collected Works, Volume 33. New York: International Publishers.

Marx, Karl. [1894] 1991. Capital. A Critique of Political Economy. Book 3. Penguin.

Marx, Karl. [1867] 1996. Karl Marx, Frederick Engels: Collected Works, Volume 35. New York: International Publishers.

Marx, Karl. [1885] 1997. Karl Marx, Frederick Engels: Collected Works, Volume 36. New York: International Publishers. 
Marx, Karl. [1894] 1998. Karl Marx, Frederick Engels: Collected Works, Volume 37. New York: International Publishers.

Marx, Karl. [1892-5] 2004. Karl Marx, Frederick Engels: Collected Works, Volume 50. New York: International Publishers.

Marx, Karl. [1864-5] 2016. Marx's Economic Manuscript of 1864-65, translated by Ben Fowkes, Historical Materialism Book Series, Volume: 100. Editor: Fred Moseley, Leiden: Brill Publishers.

Marx, Karl. [1894] 2004. Das Kapital. Kritik der politischen Ökonomie. Dritter Band. Hamburg 1894. In MEGA ${ }^{2}$ Bd. II/15. Bearb. Regina Roth, Eike Kopf und Carl-Erich Vollgraf. Unter Mitwirkung von Gerald Hubmann. Mit einer Einführung von Bertram Schefold. Hrsg. v. der Internationalen Marx-Engels-Stiftung. Berlin: Akademie Verlag.

Marx, Karl. [1868-81] 2008. Manuskripte zum zweiten Buch des «Kapitals». In MEGA² Bd. II/11. Bearb. von Teinosuke Otani, Ljudmila Vasina und Carl-Erich Vollgraf. Unter Mitwirkung von Kenji Mori und Regina Roth. Hrsg. v. der Internationalen Marx-EngelsStiftung. Berlin: Akademie Verlag.

May, Kenneth. 1948. "Value and Price of Production: a Note on Winternitz' Solution." The Economic Journal 58 (232):596-599.

Meek, Ronald L. 1956. "Some Notes on the 'Transformation Problem'." The Economic Journal 66 (261):94-107.

Mohun, Simon. 1994. "A Re(in)statement of the Labour Theory of Value." Cambridge Journal of Economics 18 (4):391-412.

Mohun, Simon, and Roberto Veneziani. 2009. "The Temporal Single-System Interpretation: Underdetermination and Inconsistency." Marxism 216 (3):277-301.

Mohun, Simon, and Roberto Veneziani. 2017. "Value, Price, and Exploitation: The Logic of the Transformation Problem.” Journal of Economic Surveys 31 (5):1387-1420.

Mongiovi, Gary. 2002. "Vulgar Economy in Marxian Garb: A Critique of Temporal Single System Marxism." Review of Radical Political Economics 34 (4):393-416.

Montes-Rojas, Gabriel. 2017. "A Capital Invariant Solution to the Marxian Transformation Problem." Review of Radical Political Economics 49 (1):114-124.

Morishima, Michio, and Francis Seton. 1961. "Aggregation in Leontief Matrices and the Labor Theory of Value.” Econometrica 29 (2):203-20.

Morishima, Michio, and George Catephores. 1978. Value, Exploitation, and Growth: Marx in the Light of Modern Economic Theory. London: McGraw-Hill.

Morishima, Michio. 1973. Marx's Economics: A Dual Theory of Value and Growth. New York and London: Cambridge University Press.

Moseley, Fred. 2016. Money and Totality: A Macro-Monetary Interpretation of Marx's Logic in Capital and the End of the 'Transformation Problem'. Leiden: Brill.

Moseley, Fred. 2020. "A Critique of Shaikh's Two Interpretations of Marx's 'Transformation Problem'." Cambridge Journal of Economics, beaa047.

https://doi.org/10.1093/cje/beaa047

Moszkowska, Natali. 1929. Das Marxsche System: Ein Beitrag zu dessen Aufbau. Berlin: Verlag Hans Robert Engelmann.

Mühlpfor[d]t, [Wolfgang]. 1895. „Karl Marx und die Durchschnittsprofitrate.“ Jahrbücher für Nationalökonomie 65:92-99.

Mühlpfordt, Wolfgang. 1893. Preis und Einkommen in der privatkapitalistischen Gesellschaft. Königsberg: Hartungsche Buchdruckerei. 
Parys, Wilfried. 2018. „Labour Values and Energy Values.” Working Papers from University of Antwerp, Faculty of Applied Economics, 2018-006, April 2018. https://repository.uantwerpen.be/docman/irua/9bc2b3/150541.pdf

Pasinetti, Luigi L. 1977. Lectures on the Theory of Production. New York: Columbia University Press.

Pasinetti, Luigi L. 2012. "Piero Sraffa and the Future of Economics." Cambridge Journal of Economics 36:1303-1314.

Potts, Nick et al. [2015] 2019. Is Marx's Theory of Profit Right?: The SimultaneistTemporalist Debate. Heterodox Studies in the Critique of Political Economy Series. Edited by Nick Potts an Andrew Kliman. Lanham • Boulder • New York • London: Lexington Books.

Pushnoi, Grigorii S. 2019. "The Modelling of the Economy by Means of C-V-M Matrices." In Christiansen, B., Sysoeva, I., Udovikina, A., \& Ketova, A. (Eds.). Emerging Economic Models for Global Sustainability and Social Development, 329-372. IGI Global. http://doi:10.4018/978-1-5225-5787-6.ch018.

Ramos-Martinez, Alejandro, and Adolfo R. Herrera. 1995. "The Transformation of Values into Prices of Production: A Different Reading of Marx's Text." In Marx and NonEquilibrium Economics, 1-28. Ed. Alan Freeman and Guglielmo Carchedi. Aldershot, UK and Brookfield, US: Edward Elgar.

Ravagnani, Fabio. 2005. “A Critical Note on Moseley's 'Macro-Monetary' Interpretation of Marx's Theory." Review of Radical Political Economy 37 (1):85-96.

Rieu, Dong-Min. 1997. "Note: A Note on the So-Called 'Double Counting' Problem in the Transformation Procedure.” Seoul Journal of Economics 10 (1):83-91.

Rieu, Dong-Min. 2003. “The Temporal Single-System Interpretation of Marx's Value Theory: a Critical Appraisal." The Korean Economic Review 19 (1):81-96.

Rieu, Dong-Min. 2006. "A Reexamination of the Quantitative Issues in the New Interpretation.” Review of Radical Political Economics 38 (2):258-271.

Rubin, Isaak I. [1928] 1990. Essays on Marx's Theory of Value. Fourth Printing. MontréalNew York: Black Rose Books.

Samuelson, Paul A. 1971. "Understanding the Marxian Notion of Exploitation: A Summary of the So-Called Transformation Problem between Marxian Values and Competitive Prices." Journal of Economic Literature 9 (2):399-431.

Sandemose, Jorgen. 2016. "On the Exposition of the Transformation of Commodity-Values into Production Prices in the Third Volume of Capital-A Textual Analysis." Theoretical Economics Letters 6:962-985.

Schefold, Bertram. 2016. "Profits Equal Surplus Value on Average and the Significance of this Result for the Marxian Theory of Accumulation." Cambridge Journal of Economics 40:165-199.

Schefold, Bertram. 2019. "The Transformation of Values into Prices on the Basis of Random Systems Revisited." Evolutionary and Institutional Economics Review 16 (2):261-302.

Schefold, Bertram. 2020. "The Transformation of Values into Prices on the Basis of Random Systems Revisited: Reply to my Commentators." Evolutionary and Institutional

Economics Review. Accessed at: https://doi.org/10.1007/s40844-020-00174-1

Schmidt, Conrad. 1889. Die Durchschnittsprofitrate auf Grundlage des Marx'schen Werthgesetzes. Stuttgart: Dietz.

Seton, Francis. 1957. “The 'Transformation Problem'.” The Review of Economic Studies 24 (3):149-160. 
Shaikh, Anwar. 1973. The So-Called Transformation Problem: Marx vindicated. New York: Mimeograph New School for Social Research.

Shaikh, Anwar. 1977. "Marx's Theory of Value and the 'Transformation Problem'." In The Subtle Anatomy of Capitalism, 106-139, ed. J. Schwartz. Santa Monica, CA: Goodyear.

Shaikh, Anwar. 2021. "Marx and the Other Sraffa: The Insignificant Empirical Effect of Price-Value Deviations on Economic Aggregates.” In Velupillai K. (eds.) Keynesian, Sraffian, Computable and Dynamic Economics, 367-85. Palgrave Macmillan, Cham. https://doi.org/10.1007/978-3-030-58131-2_16

Shibata, Kei. 1933. "Marx's Analysis of Capitalism and the General Equilibrium Theory of the Lausanne School." Kyoto University Economic Review 8 (1):107-136.

Shibata, Kei. 1939. “On the General Profit Rate." Kyoto University Economic Review 14 (1):40-66.

Sinha, Ajit. 2019. "Marx's Metaphysics of Human Labour in the Light of Sraffa: Labour Theory of Value Reconsidered." In Gupta S., Musto M., Amini B. (eds.) Karl Marx's Life, Ideas, and Influences, 289-317. Marx, Engels, and Marxism's book series (MAENMA). Palgrave Macmillan, Cham.

Sombart, Werner. 1894. „Zur Kritik der ökonomischen Systems von Karl Marx.“ Archiv für soziale Gesetzgebung und Statistik VII:555-94.

Sraffa, Piero. 1960. Production of Commodities by Means of Commodities. Prelude to a Critique of Economic Theory. Cambridge: Cambridge University Press.

Steedman, Ian. 1977. Marx after Sraffa. London: New Left Books.

Sweezy, Paul M. 1942. The Theory of Capitalist Development. New York: Monthly Review Press.

Sweezy, Paul M., ed. 1949. Karl Marx and the Close of His System \& Böhm-Bawerk's Criticism of Marx. New York: Augustus M. Kelley.

Tugan-Baranowsky, Michael von. 1905. Theoretische Grundlagen des Marxismus. Leipzig: Verlag von Duncker \& Humblot.

Veneziani, Roberto. 2004. "The Temporal Single-System Interpretation of Marx's Economics: A Critical Evaluation.” Metroeconomica 55 (1):96-114.

Winternitz, Joseph. 1948. "Values and Prices: A Solution of the So-Called Transformation Problem." The Economic Journal 58 (230):276-280.

Wolff, Richard D., Roberts Bruce, and Antonio Callari. 1982. "Marx's (not Ricardo's) 'Transformation Problem': A Radical Reconceptualization." History of Political Economy 14 (4):564-82.

Wright, Ian. 2019. "Marx's Transformation Problem and Pasinetti's Vertically Integrated Subsystems." Cambridge Journal of Economics 43 (1):169-186.

Yoshihara, Naoki, and Roberto Veneziani. 2013. "Exploitation of Labour and Exploitation of Commodities: A 'New Interpretation'.” Review of Radical Political Economics 45 (4):517-524.

Yoshihara, Naoki. 2017. "A Progress Report on Marxian Economic Theory: On the Controversies in Exploitation Theory since Okishio (1963)." Journal of Economic Surveys $31(5): 1421-14$. 